IZA DP No. 5698

Tying Your Enemy's Hands in Close Races:

The Politics of Federal Transfers in Brazil

Fernanda Brollo

Tommaso Nannicini

May 2011 


\title{
Tying Your Enemy's Hands in Close Races: The Politics of Federal Transfers in Brazil
}

\author{
Fernanda Brollo \\ University of Alicante
Bocconi University, IGIER
and IZA \\ Tommaso Nannicini
}
Discussion Paper No. 5698
May 2011

IZA

P.O. Box 7240

53072 Bonn

Germany

Phone: +49-228-3894-0

Fax: +49-228-3894-180

E-mail: iza@iza.org

Any opinions expressed here are those of the author(s) and not those of IZA. Research published in this series may include views on policy, but the institute itself takes no institutional policy positions.

The Institute for the Study of Labor (IZA) in Bonn is a local and virtual international research center and a place of communication between science, politics and business. IZA is an independent nonprofit organization supported by Deutsche Post Foundation. The center is associated with the University of Bonn and offers a stimulating research environment through its international network, workshops and conferences, data service, project support, research visits and doctoral program. IZA engages in (i) original and internationally competitive research in all fields of labor economics, (ii) development of policy concepts, and (iii) dissemination of research results and concepts to the interested public.

IZA Discussion Papers often represent preliminary work and are circulated to encourage discussion. Citation of such a paper should account for its provisional character. A revised version may be available directly from the author. 
IZA Discussion Paper No. 5698

May 2011

\section{ABSTRACT}

\section{Tying Your Enemy's Hands in Close Races: The Politics of Federal Transfers in Brazil ${ }^{*}$}

This paper uses a quasi-experimental strategy to disclose utterly political reasons behind the allocation of intergovernmental transfers in a federal state. We apply a regression discontinuity design in close elections to identify the effect of political alignment on federal transfers to municipal governments in Brazil. We find that municipalities where the mayor is affiliated with the coalition of the Brazilian President receive larger (discretionary) infrastructure transfers by about $40 \%$ in pre-election years. This effect is mainly driven by the fact that the federal government penalizes municipalities run by mayors from the opposition coalition who won by a narrow margin, thereby tying their hands for the next election.

JEL Classification: C21, D72, H77

Keywords: federal transfers, political alignment, regression discontinuity

Corresponding author:

Tommaso Nannicini

Department of Economics

Bocconi University

Via Roentgen 1

20136 Milan

Italy

E-mail: tommaso.nannicini@unibocconi.it

\footnotetext{
* We thank Alberto Alesina, Filipe Campante, Claudio Ferraz, Giovanni Mastrobuoni, and seminar participants at ASSET 2010 Alicante, Bristol University, EIEF Rome, Erasmus University Rotterdam, ESWC 2010 Shangai, IGIER, LACEA 2010 Medellin, LSE, NBER Political Economy Public Finance workshop 2010, ParisX, Petralia workshop 2010, Porto Cervo workshop 2010, PUC Rio, RES 2011 London, Universidad del Rosario Bogotà, and Universitat Autonoma de Barcelona for their extremely helpful comments. All errors are ours and follow a random walk. Brollo acknowledges financial support from the Spanish "Ministerio de Ciencia y Tecnología" and Feder Funds (project SEJ-2007-62656), Nannicini acknowledges financial support from the European Research Council (grant No. 230088).
} 


\section{Introduction}

In a federal state, transfers from the central government to lower-tier administrative units are a crucial ingredient both for the efficient provision of public goods and services, and for the competition between political actors. A large body of research in public finance has investigated the normative justifications of transfers (e.g., see Oates, 1972). From a political economy perspective, however, it is hard to believe that central governmentsbecause of either their own preferences or institutional and political constraints - behave as a benevolent social planner would do, that is, using conditional matching grants to internalize externalities or intergovernmental transfers for redistributive purposes. Indeed, although federations usually adopt allocation rules that shelter the distribution of transfers from political distortions, incumbent politicians have a lot of discretion in using them to tease swing voters, reward core supporters, or build alliances with other politicians. In other words, using Cox's (2009) taxonomy, real-world distributive politics might respond to the vote-producing goals of persuasion of unattached voters, mobilization of attached voters, or coordination among political parties.

In this paper, we apply a Regression Discontinuity Design (RDD) in close electoral races to disclose utterly political reasons behind the allocation of central transfers to local governments in Brazil. In particular, we identify the impact of political alignment between the mayor and the Brazilian President on the amount of federal transfers to municipalities. The intuition behind our identification strategy is simple. If random factors - for example, unexpected breaking news or rain on election day-played even a small role in deciding electoral outcomes, the victory of the mayoral candidate aligned with the President would mimic random assignment in those municipal elections decided by a narrow margin. The RDD setup therefore delivers a (local) source of exogenous variation in political alignment. Consistently with the Brazilian multi-party system, we measure political alignment with respect to both the government coalition and the political party of the President.

The theoretical literature has provided contrasting explanations for politically motivated transfers, or tactical redistribution. ${ }^{1}$ On the one hand, incumbent politicians may use intergovernmental transfers to increase their (or their allies') reelection probability at

\footnotetext{
${ }^{1}$ See Cox (2009) for a survey on the political economy of distributive politics.
} 
the central and local level, therefore allocating larger transfers to localities where swing voters are overrepresented (see Lindbeck and Weibull, 1987; Dixit and Londregan, 1998). On the other hand, politicians may decide to use transfers to reward their core supporters (see Cox and McCubbins, 1986). ${ }^{2}$ Irrespective of the degree of political competition, however, as far as local governments can claim some political credit for the resources they receive from the central government, the alignment between the two layers of government - that is, whether they belong to the same political coalition or not-is expected to increase the amount of transfers, because the central government has an incentive to favor its (political) friends and penalize its (political) enemies.

Testing the above hypothesis has proven to be a difficult endeavor. Without a credible source of exogenous variation in political alignment, the empirical correlation between alignment and larger transfers (if any) could be completely driven by (local) socio-economic conditions affecting both electoral outcomes and the allocation of government revenues. Most of the early studies have tackled this issue with a "selection on observables" assumption, controlling for different measures of the normative and political determinants of transfers. In the U.S., Grossman (1994) finds that the similarity of party affiliation between federal and state politicians increases grants made to a state; Levitt and Snyder (1995) show that the share of democratic voters is an important predictor of federal transfers to a district, especially in years of democratic control in Congress. In Australia, Worthington and Dollery (1998) also detect some tactical distribution of grants. This approach, however, is likely to suffer from a problem of omitted bias.

Recent studies have improved upon the earlier literature by using panel estimators. Solé-Ollé and Sorribas-Navarro (2008) use data on Spain and implement a diff-in-diff strategy, both across time (exploiting the within-municipality variation in political alignment induced by subsequent elections) and across grantors (exploiting the within-municipality variation in political alignment with different layers of government). They find that municipalities aligned with the two upper-tier governments receive over $40 \%$ more grants than

\footnotetext{
${ }^{2}$ The "swing voters" hypothesis with respect to intergovernmental grants has received empirical support for Albania (Case, 2001) and Sweden (Johansson, 2003). Looking at different outcomes, the share of unaligned voters has been shown to be positively correlated with presidential campaigning in the US (Stromberg, 2008) and the quality of politicians in Italy (Galasso and Nannicini, 2011). On the contrary, Larcinese, Rizzo, and Testa (2006) find support for the "core supporters" hypothesis in the allocation of the U.S. federal budget, as states that heavily supported the President receive more funds.
} 
unaligned municipalities. Other studies control for (time-invariant) confounding factors in a fixed-effect framework. In India, Arulampalam et al. (2009) find that aligned states receive larger grants, especially if they are swing states. Larcinese, Rizzo, and Testa (2006) study the allocation of the U.S. federal budget and show that states whose governors belong to the same party of the President receive more funds. Also for the U.S., Berry, Burden, and Howell (2010) use a large panel data set of federal outlays and show that districts and counties receive more money when their legislators are aligned with the federal President. In Portugal, Veiga and Pinho (2007) find evidence of distortions favoring municipalities ruled by the Prime Minister's party during the early years of democracy, but not in the period of established democracy.

Yet, unobservable confounding factors might be time-varying as well. For example, the occurrence of an international economic crisis could swing a large fraction of voters in export-oriented regions toward a given political party, and at the central level the same party could decide to favor these regions because of its policy preferences rather than tactical motivations. In this respect, our econometric strategy improves internal validity, because it accommodates for both time-invariant and time-varying confounding factors.

The close-election RDD setup not only has a comparative advantage in internal validity, but also addresses another relevant question, namely the interaction between the degree of competition and political alignment in shaping the tactical allocation of federal transfers. By contrasting close versus safe electoral races, we can shed light on how the effect of alignment varies along this dimension. The only limitation of this setup is that, in order to ensure internal validity in the Brazilian multi-party system, we must restrict the sample to elections where there are two (or at most three) candidates, and one of them is affiliated with the coalition or party of the President. Although this restriction only affects external validity, we show that benchmark estimations with OLS and diff-in-diff deliver the same results both in the all sample and in our two-candidate (or three-candidate) races.

To obtain a better understanding of the (reduced-form) RDD results, we frame the above issues into a simple model, where the central government allocates transfers to local governments in order to maximize both the citizens' goodwill toward itself and the political capital represented by aligned mayors, who are influential opinion leaders at the local level and may turn to be important supporters at the next federal election. If the 
central government were able to obtain full political credit for the transfers, it would only care about the citizens' goodwill and would be indifferent between benefiting aligned versus unaligned mayors. On the contrary, if voters were partly unable to distinguish the source of municipal revenues and there were some political credit spillovers in favor of local governments, aligned municipalities should end up receiving more transfers, as the central government would try either to help aligned mayors to get reelected or to hamper the reelection prospects of unaligned mayors. ${ }^{3}$ Among aligned municipalities, those where the incumbent won by a narrow margin should receive more, because it is especially there that larger municipal revenues can make a difference in the next election. By the same token, among unaligned municipalities, those where the incumbent won by a narrow margin should receive less, because the federal government wants to tie the hands of its political enemies. Furthermore, all of these effects should be stronger where (i) the impact of transfers on reelection is higher (for instance, where the mayor faces no term limit and puts more effort in the campaign), and (ii) the value of political capital is higher (for instance, where local politicians have a stronger influence on the public opinion).

The close-race RDD setup is particularly suited to test the theoretical predictions. According to our empirical results, in races decided by a narrow margin, municipalities where the mayor is affiliated with the political coalition of the Brazilian President receive larger (discretionary) transfers in infrastructure by about one-third in the last two years of the mayoral mandate, that is, when the next municipal elections are approaching. During the first two years of the mandate, when instead federal elections are approaching, we find no evidence of political distortions in the allocation of federal transfers. This is consistent with the hypothesis of political credit spillovers mentioned above, as it seems that opportunistic transfers take place in proximity of municipal rather than federal elections. Consistently with our model, the effect of political alignment is driven by a sizable cut in transfers to unaligned municipalities close to the discontinuity of zero margin of victory. In other words, there is evidence that the federal government penalizes municipalities ruled by mayors who belong to the opposition coalition and won by a narrow margin (the "tying hands" effect). On the other side of the discontinuity, however, we find no evidence that

\footnotetext{
${ }^{3}$ On contested credit claiming in distributive politics, see Shepsle et al. (2009), who show that the members of the U.S. House and Senate delegations within each state must share the credit for appropriations that originate in their chamber with the delegation members in the other chamber.
} 
the federal government mostly targets those aligned municipalities where the mayor won by a narrow margin; on the contrary, the political strongholds of the President's coalition tend to receive larger transfers. Political alignment has also a positive impact on the incumbent mayor's reelection probability and on the President's vote share in the future federal election, although these results are less robust and more volatile.

The effect of political alignment on federal transfers is heterogeneous along the lines predicted by our theoretical framework. First, the effect of political alignment is higher (i) in municipalities without a local radio station, and (ii) in small municipalities. We interpret this as evidence that the impact of alignment is higher if the value of political capital for the central government is larger (for instance, where municipal institutions are important opinion leaders and the main source of political information for citizens). Second, the effect is higher (i) for mayors without a binding term limit, (ii) for mayors who are not aligned with the state governor, and (iii) for municipalities characterized by high turnout rates. We interpret these findings as evidence that the impact of alignment is magnified by how effective transfers are in producing votes (for instance, because the incumbent mayor exerts more effort in getting reelected or has a hard time obtaining transfers from other sources, such as the state government).

The remainder of the paper is organized as follows. In Section 2, we present our theoretical framework. In particular, in Section 2.1 we introduce a simple model setting the stage for the empirical analysis; in Section 2.2 we derive our identification strategy. In Section 3, we discuss the relevant Brazilian institutions and describe our data. In Section 4, we present the empirical results and validity tests. We conclude with Section 5.

\section{Theoretical Preliminaries}

\subsection{A simple model}

Consider the (political) maximization problem of a central government (or President) that must choose the amount of federal transfers $\tau_{i}$ to allocate to each local government $i$, with $i=1, \ldots, N$. The President's objective function is made up of two (political) benefits. On the one hand, he will try to increase the general goodwill of the citizens in every municipality $i$ toward the central government; and this is assumed to be a positive 
function of the amount of transferred resources: $U\left(\tau_{i}\right)$, with $U^{\prime}>0, U^{\prime \prime}<0$. On the other hand, he will try to increase the likelihood that municipality $i$ is run by a mayor aligned with the central government, either because local politicians are important opinion leaders and they may turn to be useful allies in the next presidential campaign, or because they may engage in rent-seeking activities for the President. If the future margin of victory of the mayoral candidate aligned with the President is positive (that is, if the President's coalition wins in municipality $i$ ), the central government increases its political capital by a positive (fixed) amount $R$. The relative weight of the two benefits, however, depends on whether voters give political credit for the increased municipal revenues to the central government or to the mayor. We define $\theta \in[0,1]$ as the political credit spillovers accruing to the incumbent mayor. In other words, if $\theta=0$ the central government can claim full credit for $\tau_{i}$, while if $\theta=1$ all the credit is going to the municipal government.

Following the above setup, the President's objective function can be expressed as:

$$
\max _{\tau_{i}}\left\{(1-\theta) \sum_{i} U\left(\tau_{i}\right)+\sum_{i} R \cdot \operatorname{Pr}\left[M V P_{i}>0\right]-\sum_{i} C\left(\tau_{i}\right)\right\},
$$

where $M V P_{i}$ is the future margin of victory of the mayoral candidate aligned with the central government in municipality $i$, and $C\left(\tau_{i}\right)$ captures the opportunity cost of allocating a certain amount of transfers, with $C^{\prime}>0, C^{\prime \prime}<0$. We assume the cost function of municipality $i$ to be independent of what happens in municipality $j \neq i$. This is in line with the Brazilian institutions that we describe below, because the discretionary transfers of our empirical analysis are a very small fraction of the federal budget. In other words, the central government could easily meet the requests of every municipality independently of each other, but meeting each individual request comes with an opportunity $\operatorname{cost} C\left(\tau_{i}\right)$, either in terms of taxation or decreased expenditure on other items of the budget. From an econometric point of view, this is equivalent to assuming that the Stable Unit Treatment Value Assumption (SUTVA) holds, as the outcome (federal transfers) of $i$ depends on the treatment (political alignment) of $i$ but not on the treatment of $j \neq i$.

The crucial point is that - in equation (1) - the margin of victory of the aligned candidate in municipality $i$ is going to be affected by federal transfers too. In particular, we assume that the transferred resources are going to increase the electoral prospects of the incumbent mayor, or of his political party. Therefore, if the incumbent is aligned with the 
President $\left(P_{i}=1\right), \tau_{i}$ will increase the future margin of victory of the politically aligned candidate, and vice versa if the incumbent is not aligned $\left(P_{i}=0\right)$. The future margin of victory of the aligned candidate can be expressed as:

$$
M V P_{i}=\rho M V P_{i}^{0}+\epsilon_{i}+\theta\left(2 P_{i}-1\right) f\left(\tau_{i}\right)
$$

where $M V P_{i}^{0}$ is the margin of victory of the aligned candidate in the previous election, $\epsilon \sim N\left(0, \sigma^{2}\right)$ is a normally distributed random shock, and $f\left(\tau_{i}\right)$ is a function that translates transfers into votes for the incumbent, with $f^{\prime}>0, f^{\prime \prime}<0$.

The persistence of the past margin of victory (captured by $\rho$ ) means that the future electoral outcome depends on the past electoral outcome, either because of the ideological bias of voters in municipality $i$ or because of an incumbency advantage. The normal shock $\epsilon_{i}$ accommodates for the presence of random events. ${ }^{4}$ The last term on the right-hand side of equation (2) captures the impact of transfers on the next municipal election. As long as there are some political credit spillovers $(\theta>0)$, the additional municipal revenues are going to help either the aligned candidate if $P_{i}=1$, or the unaligned candidate if $P_{i}=0 .{ }^{5}$ Indeed, the assumption that higher transfers from the central government increase the reelection probability of the incumbent mayor or party has been corroborated by many empirical studies, also on Brazil. ${ }^{6}$ It follows that:

$$
\operatorname{Pr}\left[M V P_{i}>0\right]=\Phi\left[\frac{\rho M V P_{i}^{0}+\theta\left(2 P_{i}-1\right) f\left(\tau_{i}\right)}{\sigma}\right],
$$

where $\Phi[$.$] is the cumulative distribution function of the standard normal.$

\footnotetext{
${ }^{4}$ The normality assumption simplifies notation, but it is not required by Proposition 1 below; Proposition 2 only requires a random shock distributed with a decreasing density on either side of zero.

${ }^{5}$ We are implicitly assuming that the impact of more municipal resources on electoral outcomes is the same for aligned and unaligned incumbents. This simplifies notation and introduces symmetry, but it comes with no loss of generality with respect to the propositions derived below.

${ }^{6}$ For Brazil, Brollo et al. (2010) and Litschig and Morrison (2010) apply an RDD in population size to estimate the impact of larger transfers on the incumbent mayor's reelection; both studies detect a positive effect in different sample periods; Brollo (2008) finds that the federal government reduces transfers to corrupt municipalities, but it helps its (political) friends to get rid of the punishment faster; Caselli and Michaels (2009) and Monteiro and Ferraz (2010) find that oil windfalls are associated with a positive incumbency advantage at the municipal level. For Uruguay, Manacorda et al. (2009) apply an RDD in the assignment criterion of an anti-poverty program and find a positive impact on the recipients' support for the government. For Spain, Solé-Ollé and Sorribas-Navarro (2008) find that grants allocated to local governments of the same party buy more political support than the others.
} 
Equilibrium transfers. Substituting the last expression into equation (1), the firstorder condition of the President's maximization problem can be written as:

$$
(1-\theta) U^{\prime}\left(\tau_{i}\right)+\frac{R \theta\left(2 P_{i}-1\right) f^{\prime}\left(\tau_{i}\right)}{\sigma} \phi\left[\frac{\rho M V P_{i}^{0}+\theta\left(2 P_{i}-1\right) f\left(\tau_{i}\right)}{\sigma}\right]-C^{\prime}\left(\tau_{i}\right)=0
$$

where $\phi[$.$] is the density function of the standard normal. Also note that, by definition,$ $P_{i}=1$ if $M V P_{i}^{0}>0$, and $P_{i}=0$ if $M V P_{i}^{0}<0$.

From this simple first-order condition, we can derive a set of testable predictions on the direction and size of politically motivated central transfers. Assume that the past margin of victory tends to either $+\infty$ or $-\infty$, or that there are no political credit spillovers $(\theta=0)$ : in both cases, transfers do not influence the future margin of victory. As a result, the central government simply weighs the marginal benefit of increasing citizens' goodwill against the marginal cost of $\tau_{i}$ : this gives the (politically) optimal amount of transfers $\tau^{*}$ in absence of tactical redistribution, such that $(1-\theta) U^{\prime}\left(\tau_{i}^{*}\right)=C^{\prime}\left(\tau_{i}^{*}\right)$.

Things change, of course, if $\theta>0$ and $M V P_{i}^{0} \in[-1,1]$. In this case, the central government chooses $\tau_{i}$ by looking at the additional marginal benefit or cost of influencing the next municipal election. Indeed, from equation (4), it is evident that the second term in the left-hand side is either positive if $P_{i}=1$ or negative if $P_{i}=0$. In other words, at the zero threshold $\left(M V P_{i}^{0}=0\right)$, there is a sharp jump in the maximization problem of the President, as the marginal cost of sending money to an unaligned incumbent suddenly becomes the marginal benefit of sending money to an aligned incumbent. This implies a strong and positive impact of political alignment on transfers in close electoral races.

Proposition 1 The (local) Average Treatment Effect (ATE) of political alignment on transfers is positive at $M V P_{i}^{0}=0$. That is: $\lim _{M V P_{i}^{0} \downarrow 0} \tau_{i}-\lim _{M V P_{i}^{0} \uparrow 0} \tau_{i}>0 .^{7}$

Furthermore, it is straightforward to show that - given the model's assumptions and the second-order condition of the President's maximization problem-politically motivated transfers are a decreasing function of the past margin of victory of the aligned candidate on both sides of the zero threshold. In fact, $\partial \tau_{i} / \partial M V P_{i}^{0}<0$ both if $P_{i}=1$ and if $P_{i}=0$. The intuition for this result is simple and follows from the persistence of the electoral outcome: on the left of the zero threshold $\left(M V P_{i}^{0}<0\right)$, the central government wants

\footnotetext{
${ }^{7}$ The proof of Proposition 1 is straightforward, but for completeness we sketch it in the Appendix.
} 
to penalize unaligned municipalities lost by a narrow margin, because especially there transfers are going to make a difference in the next election; by the same token, on the right of the zero threshold $\left(M V P_{i}^{0}>0\right)$, the central government wants to favor aligned municipalities won by a narrow margin.

Proposition 2 The amount of politically motivated transfers is a decreasing function of $M V P_{i}^{0}$ on either side of the threshold $M V P_{i}^{0}=0$. That is: $\partial \tau_{i} / \partial M V P_{i}^{0}<0 .{ }^{8}$

These theoretical results are graphically shown in Figure 1, where the optimal amount of politically motivated transfers to municipality $i$ is expressed as a function of the past margin of victory. There, the dashed horizontal line represents $\tau^{*}$, while the solid lines on the two sides of the zero threshold are the optimal transfers decided by the central government on the basis of the ex-ante level of political competition in unaligned (on the left of zero) versus aligned (on the right of zero) municipalities. The sharp jump at zero is the local treatment effect of political alignment in close elections.

Comparative statics. The theoretical framework also delivers predictions of comparative statics. In particular, the size of the causal impact of political alignment on transfers in close elections depends on the model's parameters. The ATE at $M V P_{i}^{0}=0$ increases if the value of political capital $(R)$ increases. In fact, by the implicit function theorem: $\partial \tau_{i} / \partial R>0$ if $P_{i}=1$; and $\partial \tau_{i} / \partial R<0$ if $P_{i}=0$. This means that in Figure 1 , as $R$ increases, the curve on the right of zero shifts upward and the curve on the left of zero shifts downward, thereby increasing the jump in optimal transfers at $M V P_{i}^{0}=0$. By the same token, it is easy to see that the ATE increases if the variance of the random shock $\left(\sigma^{2}\right)$ decreases. In fact, in this case: $\partial \tau_{i} / \partial \sigma<0$ if $P_{i}=1 ; \partial \tau_{i} / \partial \sigma>0$ if $P_{i}=0$. By a slight abuse of notation, we could also state that the ATE increases if the marginal impact of transfers on votes $\left(f^{\prime}\left(\tau_{i}\right)\right)$ increases. Assuming $f($.$) to be linear, for instance, would$ deliver the same comparative statics result obtained on $R$ for the political effectiveness of transfers. The impact of political credit spillovers - as captured by $\theta$ - is instead unclear, because the relationship between $\theta$ and the optimal $\tau$ turns out to be ambiguous.

\footnotetext{
${ }^{8}$ To obtain interior solutions, we are implicitly assuming that the first-order condition in equation (4) - evaluated at $P_{i}=0, \tau=0$, and $M V P_{i}^{0}=0$ - is strictly positive. The proof of Proposition 2 easily follows from the implicit function theorem and is sketched in the Appendix.
} 


\section{$2.2 \quad$ Identification and estimation}

The close-race RDD setup (see Lee, 2008) is particularly suited to take the above theoretical predictions to the data and estimate the causal effect of political alignment on the amount of (discretionary) federal transfers. Define $\tau_{i m}(1)$ as the potential transfers received by municipality $i$ during the administrative mandate $m$ if the mayor is politically aligned with the President, and $\tau_{i m}(0)$ as the potential transfers of the same municipality if the mayor is not aligned with the President. The variable $P_{i m}$ defines the treatment status: $P_{i m}=1$ if there is political alignment, and $P_{i m}=0$ otherwise. The observed outcome is thus: $\tau_{i m}=P_{i m} \cdot \tau_{i m}(1)+\left(1-P_{i m}\right) \cdot \tau_{i m}(0)$. The estimand of interest is the ATE, $E\left[\tau_{i m}(1)-\tau_{i m}(0)\right]$, defined over some subpopulation of interest.

Define $W_{i}$ as a set of relevant municipality-specific covariates (including state fixed effects), $X_{i m}$ as a set of (mandate-varying) mayoral characteristics, and $\delta_{m}$ as mandate fixed effects. In the OLS estimation

$$
\tau_{i m}=\alpha+\pi P_{i m}+W_{i}^{\prime} \beta+X_{i m}^{\prime} \phi+\delta_{m}+\varepsilon_{i m},
$$

the estimated $\hat{\pi}$ is based on the conditional comparison of the observed transfers of aligned versus unaligned municipalities, which does not generally provide an unbiased estimate of the ATE, as long as towns with different unobservable characteristics affecting federal transfers self-select into political alignment by voting for different parties.

A diff-in-diff estimator can instead control for time-invariant confounding factors by means of municipality fixed effects $\gamma_{i}$ :

$$
\tau_{i m}=\alpha+\pi P_{i m}+X_{i m}^{\prime} \phi+\gamma_{i}+\delta_{m}+\varepsilon_{i m} .
$$

Also in this estimation, however, $\hat{\pi}$ might fall short of providing an unbiased estimate of the ATE. In particular, unobservable confounding factors might be time-varying too.

In order to deal with the presence of both time-invariant and time-varying confounding factors, we implement an RDD strategy in the spirit of Lee (2008) and compare municipalities where the politically aligned candidate barely won with municipalities where the politically aligned candidate barely lost. ${ }^{9}$ Specifically, we calculate the margin of victory

\footnotetext{
${ }^{9}$ See also Lee, Moretti, and Butler (2004). Ferreira and Gyourko (2009) and Pettersson-Lidbom (2008) use the same identification strategy to estimate the impact of political parties with different ideologies on
} 
of the mayoral candidate politically aligned with the Brazilian President in each municipality $i$ and mandate $m\left(M V P_{i m}\right) .{ }^{10}$ This measure is thus positive in municipalities where the mayor belongs to the central government coalition, and negative otherwise. At the zero threshold, $M V P_{i m}=0$, political alignment $P_{i m}$ sharply changes from zero to one. This treatment assignment mechanism is an example of sharp RDD and delivers a direct test of Proposition 1 in our theoretical framework.

$M V P_{i m}$ can be seen as a random variable depending on observable and unobservable variables, as well as on random events on election day (the shock $\epsilon_{i}$ in our model). Lee (2008) shows that identification requires that: (i) for each political candidate, the probability of winning is never equal to zero or one; (ii) for each political candidate, the probabilities of winning or losing the election by a narrow margin are identical. ${ }^{11}$ In other words, electoral outcomes depend on both predictable elements and random chance, but the latter is crucial only when the race is close. The ATE in close elections is thus:

$$
E\left[\tau_{i m}(1)-\tau_{i m}(0) \mid M V P_{i m}=0\right]=\lim _{\epsilon \downarrow 0} E\left[\tau_{i m} \mid M V P_{i m}=\epsilon\right]-\lim _{\epsilon \uparrow 0} E\left[\tau_{i m} \mid M V P_{i m}=\epsilon\right]
$$

Equation (7) expresses a local effect, which cannot be extrapolated to the whole population without additional homogeneity assumptions. ${ }^{12}$

Various methods can be used to estimate the local ATE expressed in equation (7). We first apply a spline polynomial approximation, that is, we fit a $p$-order polynomial in

policy outcomes in the U.S. and Sweden, respectively. Gagliarducci, Nannicini, and Naticchioni (2011) use a close-election RDD strategy to estimate the impact of majoritarian versus proportional elections on targeted redistribution and rent extraction.

${ }^{10}$ This corresponds to $M V P_{i}^{0}$ in the theoretical model; we omit the superscript for the sake of simple notation. We use two different measures of political alignment according to either the government coalition or the political party of the President; see Section 3.3 for more details.

${ }^{11}$ These conditions are equivalent to the standard RDD assumption that potential outcomes must be a continuous function of the running variable at the threshold (Hahn, Todd, and Van der Klaauw, 2001).

${ }^{12}$ This effect, however, is exactly what Proposition 1 predicts. Note that the fact that our model predicts that the central government can use transfers to target electoral races decided by a narrow margin does not violate the RDD identification assumptions. In fact, in the real world, there are two possible responses to this strategy. First, the opposition coalition might reply by targeting the same races with its own political instruments (e.g., campaigning time and money); in this case, from one election to the next, the level of political competition would change only because of random shocks. Second, the opposition coalition might be constrained in its political instruments; in this case, the central government could shift the past close races in its favor, but, still, there will be some other races decided by a narrow margin at the next electoral cycle. Indeed, ex-post close races are different from ex-ante close races and this ensures that the (local) assignment into treatment is as good as random. 
$M V P_{i m}$ on either side of the threshold $M V P_{i m}=0$ :

$$
\tau_{i m}=\sum_{k=0}^{p}\left(\rho_{k} M V P_{i m}^{k}\right)+P_{i m} \sum_{k=0}^{p}\left(\pi_{k} M V P_{i m}^{k}\right)+\delta_{m}+v_{s}+\eta_{i m},
$$

where $\delta_{m}$ are mandate fixed effects, and $v_{s}$ state fixed effects. The estimated coefficient $\hat{\pi}_{0}$ identifies the ATE at the zero threshold, and we expect $\hat{\pi}_{0}>0$ to validate Proposition 1 . Standard OLS inference procedures can be applied; we also cluster standard errors at the town level, because the same municipality may be observed in repeated mayoral terms.

An additional advantage of equation (8) is that the shape of the polynomial on the left of zero (i.e., the estimated coefficients $\hat{\rho}_{k}$ ) and of the polynomial on the right of zero (i.e., the estimated coefficients $\hat{\pi}_{k}$ ) can indirectly test Proposition 2, that is, they can tell us something on the relationship between the level of political competition and discretionary transfers to the President's (political) friends or enemies. Because the assignment to political alignment is endogenous as we move far away from zero, however, this evidence ought to be interpreted with caution.

The above spline polynomial estimation is attractive for many reasons, although a possible concern is that it may be sensitive to outcome values for observations far away from the threshold (see Imbens and Lemieux, 2008). To control for this, we also apply the local linear regression approach, which restricts the sample to municipalities in the interval $M V P_{i m} \in[-h,+h]$ and estimates the model:

$$
\tau_{i m}=\rho_{0}+\rho_{1} M V P_{i m}+\pi_{0} P_{i m}+\pi_{1} P_{i m} \cdot M V P_{i m}+\delta_{m}+v_{s}+\eta_{i m},
$$

where $\delta_{m}$ are mandate fixed effects, $v_{s}$ state fixed effects, standard errors are clustered at the town level, and the optimal bandwidth $h$ is selected as in Imbens and Kalyanaraman (2009). Again, $\hat{\pi}_{0}$ identifies the ATE at the zero threshold.

Finally, to evaluate the comparative statics of our model, we check for treatment effect heterogeneity in separate subsamples. The intuition for this test is simple. Assume that $D_{i m}$ captures a given heterogeneity dimension, which can be interpreted as a good proxy for either political capital or the marginal impact of transfers on votes. We estimate:

$$
\begin{array}{r}
\tau_{i m}=\sum_{k=0}^{p}\left(\rho_{k} M V P_{i m}^{k}\right)+P_{i m} \sum_{k=0}^{p}\left(\pi_{k} M V P_{i m}^{k}\right)+ \\
+D_{i m} \cdot\left[\sum_{k=0}^{p}\left(\alpha_{k} M V P_{i m}^{k}\right)+P_{i m} \sum_{k=0}^{p}\left(\beta_{k} M V P_{i m}^{k}\right)\right]+\delta_{m}+v_{s}+\xi_{i m} .
\end{array}
$$


As a result, $\hat{\pi}_{0}$ identifies the treatment effect in $D_{i m}=0, \hat{\pi}_{0}+\hat{\beta}_{0}$ in $D_{i m}=1$, and $\hat{\beta}_{0}$ the difference between the two. If $D_{i m}$ measures the importance of political capital for the central government, we expect $\hat{\beta}_{0}>0$. Similarly, if $D_{i m}$ measures the effectiveness of additional revenues in terms of the electoral outcome, we expect $\hat{\beta}_{0}>0$.

\section{Institutions and Data}

\subsection{The Brazilian federal system}

Brazilian politics takes place in the framework of a federal presidential democracy and of a multi-party system. The Brazilian territory is divided in 26 states and one federal district (Brasilia), ruled by a governor and a legislative assembly. Municipalities are the lowest layer of administrative division, and are ruled by an elected mayor (Prefeito) and by an elected city council (Camera dos Vereadores). Municipal governments are in charge of a relevant share of the provision of public goods and services related to education, health, and infrastructure projects. President, governors, and mayors of municipalities above 200,000 voters are directly elected with (runoff) majority rule, while mayors of municipalities below 200,000 are directly elected with plurality rule. Deputies and senators are elected with open-list proportional representation, and the same holds for state deputies and city councillors. The elections of the President, governors, and members of Congress all take place at the same time every four years, while municipal elections are staggered by two years and also take place every four years.

The Brazilian party system is highly fragmented, and the composition of coalition governments has constantly changed over time. In particular, the fragmentation of the party system increased in the late 1980s, because of a new legislation easing the requirements for party organization, and because of an exodus from the two largest parties at that time, PMDB (Partido do Movimento Democrático Brazileiro) and PFL (Partido da Frente Liberal). Nowadays, there are 27 officially registered parties. Besides PMDB and PFL, PT (Partido dos Trabalhadores) and PSDB (Partido da Social-Democracia Brasileira) are the most important of them. The current President is Dilma Vana Rousseff Linhares, elected in October 2010 and affiliated with PT. ${ }^{13}$ After the 2010 parliamentary election, PT be-

\footnotetext{
${ }^{13}$ Oath of office always takes place in January of the year following the presidential election.
} 
came the largest party in the Congress, and it also rules some states and major cities. The former Presidents were Luiz Inácio Lula da Silva, also affiliated with PT, who was elected in October 2002 and reelected in October 2006; and Fernando Henrique Cardoso, from PSDB, who was elected in October 1994 and reelected in October 1998. PSDB rules the two biggest Brazilian states, Sao Paulo and Minas Gerais. However, PMDB is the largest party measured by number of affiliates and by number of mayors, and it was the largest party measured by parliamentary seats over our sample period. Because of its relevance and median position in the ideological spectrum, PMDB usually supports the government; indeed, it is a member of the current government coalition and it was so in both Cardoso's mandates and in the second of Lula's mandates. Among the main parties, PFL is the more right-oriented and is concentrated in the Northeast of Brazil. Note that our sample encompasses part of both Cardoso's and Lula's tenure in office.

Brazil has a weakly institutionalized party system, with high electoral volatility, low levels of party identification in the electorate, high fragmentation, and lack of strong ideological platforms. Following the Constitution of 1988, however, all Presidents have been able to build reasonably stable post-electoral government coalitions by means of several discipline devices, such as veto power on the main issues, special prerogatives on budget allocation - including federal transfers - and the strong power of the leaderships of the coalition parties (see Figueiredo and Limongi, 2000; Pereira and Mueller, 2002).

\subsection{The allocation of federal transfers}

The resources of Brazilian municipalities come from (i) local revenues, such as fines, exemptions, service taxes, and residential property taxes; and (ii) transfers from the federal, state, or other municipal governments. The most important source of municipal revenues is represented by federal transfers, which on average amount to $65 \%$ of the municipal budget. Basically, there are two types of federal transfers: (i) Constitutional automatic transfers, mostly unrestricted (Fundo de Participacao do Municipios, FPM) or tied to education and health programs; and (ii) discretionary transfers (CONVÊEIO), mostly related to infrastructure projects. Excluding some big cities, such as Brazilian state capitals, municipal governments are strongly dependent on these transfers for their budget, as tax revenues average to only $5.5 \%$ of municipal total revenues. 
In this study, we focus on discretionary federal transfers devoted to infrastructure projects, which amount to about $15 \%$ of total municipal expenditure in infrastructures. These transfers are related to budget items that involve the construction of buildings and bridges, the paving of roads, the improvement of water and sewer systems, the purchase of ambulances, and so on. We focus on this type of federal transfers because the bulk of the other revenues are largely non-discretionary and hard to manipulate. ${ }^{14}$ Furthermore, such transfers are used to finance highly visible projects, that is, they are an ideal target for politicians willing to tease voters. Although mayors have to exert some effort in applying for these discretionary transfers, the legislative and the executive have an important role in defining their precise allocation. The support of a federal deputy and the final consent of the President are crucial ingredients of the allocation mechanism.

Basically, the annual budget law (Lei Orçamentária Anual) is first drafted by the executive, and it is then subject to (individual or collective) amendments by legislators. In most cases, the municipalities that will receive discretionary transfers are chosen by legislators trying to bring the pork home, as the bulk of the proposed amendments include targeted benefits to local areas. There are limits, however, to the number and value of the amendments that can be proposed by legislators. The Budget Committee is in charge of authorizing the bill. After a period of discussion, Congress votes for the budget law, which is then sent back to the President for the final decision. As the budget law is not mandatory in Brazil, the President has a major role in deciding the exact allocation of the discretionary transfers and can thus use them to make deputies follow the guidelines of the government coalition. Municipal governments must also exert some effort to receive these transfers, because a budgetary amendment can be executed only when an agreement between the municipality and the central government is signed.

At the end of the day, voters in a given municipality will receive discretionary infrastructure transfers depending on three factors: (i) The effort of their municipal administration; (ii) the interest of a federal deputy; and (iii) the interest of the President in executing the budget amendment (i.e., send the money exactly to that municipality). The federal President has the last word in the decision process, though. Because of the institutional

\footnotetext{
${ }^{14}$ As a falsification test, we also performed RDD estimations on Constitutional automatic transfers (FPM), detecting no effect of political alignment on their allocation (results available upon request).
} 
and political context described in the previous section, the President usually faces the hard task of passing the legislative agenda in a Congress where there are a lot of parties, and where the President's party usually controls less than 20 percent of the seats. Discretionary transfers to specific areas are therefore one of the instruments that the President can use to unify the government coalition in the Congress.

\subsection{Sample selection and descriptive statistics}

Every two years there are elections in Brazil. Federal elections and municipal elections take place separately; their exact timing over our sample period is illustrated in Figure 2. Our study encompasses federal governments in office during the three four-year mandates from 1999 to 2002, from 2003 to 2006, and from 2007 to 2010; as well as municipal administrations in office during the three four-year mandates from 1997 to 2000, from 2001 to 2004, and from 2005 to 2008. Our baseline results consider federal transfers only in the last two years of each mayoral mandate, that is, the per-capita amount of infrastructure transfers for the periods 1999-2000, 2003-2004, and 2007-2008. For transfers in 1999 and 2000, the President was Fernando Henrique Cardoso , while for transfers since 2003 the President was Luis Inácio Lula da Silva. The choice of the timing is motivated by the fact that we want to capture opportunistic transfers in proximity of upcoming municipal elections. As a second step, however, we also check whether opportunistic transfers take place in proximity of federal rather than municipal elections. We thus build an alternative measure of federal transfers, referring to the first two years (last two years) of each municipal (federal) mandate: 1997-1998, 2001-2002, and 2005-06. In our data, federal transfers are measured in per-capita real values expressed in 2000 Brazilian reais.

As for the treatment, we define two different variables capturing whether the municipality is politically aligned with the federal President or not. The first measure indicates if the mayor belongs to a party in the federal government coalition, and the second measure indicates if the mayor belongs to the President's party. In Table 1, we provide details on the political parties included in the federal government coalition year by year.

In order to implement our identification strategy in the Brazilian multi-party system along the lines discussed in Section 2.2, we must restrict our sample to municipalities where only two (or at most three) candidates ran for mayor and one of them was politically 
aligned with the federal President. This is due to the fact that the assignment to political alignment can be considered as good as random only if the mayoral candidate aligned with the President had a fair chance of winning the election.

This sample selection procedure improves internal validity, but it comes at the price of lower external validity. The races with only two candidates amount to $51 \%$ of the total, while races with only three candidates amount to $31 \%$, so that races with at most three candidates represent $82 \%$ of all municipal elections. If we further restrict the sample to elections where the aligned mayor belonged to the first two (or three) candidates, we end up with a sample of two-candidate races that covers $42 \%(19 \%)$ of the total when we look at the President's coalition (party). With three-candidate races, we end up with a sample that covers $55 \%(28 \%)$ of the total when we look at the President's coalition (party). This means that, starting from the entire sample of 22,287 elections, we can implement our RDD strategy in four distinct subsamples: (i) two-candidate races with at least one candidate belonging to the President's coalition $(5,723)$; (ii) two-candidate races with respect to the President's party $(2,612)$; (iii) three-candidate races with respect to the coalition $(12,245)$; (iv) three-candidate races with respect to the party $(6,248)$.

To evaluate what we lose in terms of external validity with the RDD sample selection, we can look at how the above subsamples differ from the rest of Brazilian municipalities. ${ }^{15}$ Table 2 (Table 3) compares two-candidate (three-candidate) races with the other municipal elections. The variables we consider are the following town-specific Census characteristics (i.e., the covariates $W_{i}$ ): population size; per-capita income; the over-20 literacy rate; the rate of urban population; the fraction of houses with access to water, sewer, or electricity; the presence of a local radio station; and geographical location.

Looking at the President's coalition, municipalities with two-candidate races are not so different from the rest, although they appear to be slightly smaller in terms of average population and less likely to have a local radio station. Municipalities with three-candidate races, despite their higher frequency, tend to be more diversified from the rest, as they are not only bigger and with a radio station, but are also better endowed of public infrastructures (i.e., house access to water, sewer, electricity). Looking at the President's

\footnotetext{
${ }^{15}$ In all specifications, we consider only municipalities with less than 200,000 inhabitants, where elections are held under plurality rule.
} 
party - not surprisingly given the even lower sample size - differences are also stark, in both two-candidate and three-candidate elections.

Furthermore, focusing on the RDD samples of two-candidate and three-candidate races, we can preliminary check if there are statistically significant differences between municipalities with a politically aligned mayor and municipalities with a politically unaligned mayor. According to the summary statistics reported in Table 4 and Table 5, municipalities aligned with the President's coalition (or the President's party) tend to receive larger per-capita transfers when municipal elections are approaching (that is, in the last two years of the mayoral mandate), while no significant difference emerges with respect to first two-year transfers. The reelection probability of aligned mayors also tend to be considerably higher. Looking at the Census characteristics, there is no evidence of "selection on observables" in our two samples. Indeed, there are no statistically significant differences between aligned and unaligned municipalities, except for three-candidate races with the President's party as a measure of political alignment. This means that in general municipalities that are politically aligned with the President do not seem to differ from the others in terms of wealth and development. This is not particularly relevant for our identification strategy - which accommodates for both selection on observables and unobservables - but it is an additional piece of information on Brazilian politics.

\section{Empirical Results}

\subsection{The effect of political alignment on federal transfers}

Our main results are reported in Table 6, which shows the benchmark OLS and diff-in-diff estimates, and in Table 7, which shows the RDD estimates. We look at two different outcomes: in the first two columns of both tables, the dependent variable is the amount of transfers in the last two years of the mayoral term (when the next municipal election is approaching); in the last two columns, the dependent variable is the amount of transfers in the first two years of the mayoral term (when the next federal election is approaching). For both dependent variables, we have two separate columns because, as discussed above, we measure political alignment referring to both the President's coalition and party. To ease comparisons, we implement the OLS and diff-in-diff specifications both in the whole 
sample and in the RDD samples of two-candidate and three-candidate elections.

According to the cross-sectional and panel evidence reported in Table 6, politically aligned municipalities receive more infrastructure transfers in the last two years of the mayoral mandate, while the estimates on the transfers received in the first two years are never statistically significant. The results of the OLS regressions in the all sample and in two-candidate (or three-candidate) elections are fairly similar between each other, for both measures of political alignment. This further reassures about the external validity of our RDD sample restriction. For all municipalities (panel A), with respect to the average level, transfers increase by $18.4 \%$ or $24.1 \%$ when the mayor belongs to the coalition or party of the President, respectively. In two-candidate (panel B) and three-candidate races (panel C), the OLS estimates point to a $27.3 \%$ (two-candidate) or $20.5 \%$ (three-candidate) effect of the coalition alignment, and to a $24.9 \%$ (two-candidate) or $35.8 \%$ (three-candidate) effect of the party alignment. The size of the diff-in-diff estimates is in the same ballpark, with just one exception: in two-candidate races, being aligned with the President's party has an effect on transfers that is almost twice as much as the other estimates (about 75\%). Diff-in-diff estimates also tend to be slightly larger than OLS. This discrepancy might be due to the fact that OLS coefficients display a downward bias. Yet, also the diff-in-diff results may suffer from time-varying omitted bias.

Table 7 reports the main RDD results in (close) two-candidate and three-candidate elections. In the two-candidate sample (panel A), according to the baseline estimation with spline polynomial approximation and full bandwidth as in equation (8), being affiliated with the coalition of the Brazilian President increases the amount of per-capita infrastructure transfers by about 36.9\%. ${ }^{16}$ The effect of being affiliated with the President's party is instead not statistically significant. In the three-candidate sample (panel B), being affiliated with the President's coalition increases transfers by about $26.3 \%$. The effect of being affiliated with the President's party amounts to $34.3 \%$, although it is significant only at a 10\% level. The RDD results on the President's coalition are a direct confirmation of Proposition 1 in our model. The fact that the results on the President's party are less robust could receive a twofold explanation: from a political point of view,

\footnotetext{
${ }^{16}$ We implement the spline polynomial approximation with a third-order polynomial, but the results are robust to the use of a second-order or fourth-order polynomial (available upon request).
} 
the Brazilian President might be forced to please his political allies even more than his own party, in order to keep the government coalition united (see the discussion in Section 3.2); from a statistical point of view, as the point estimates on the President's party are fairly similar to those on the President's coalition, the lower significance might be a problem of accuracy induced by the reduced sample size.

In Table 7, we also implement local linear regression with optimal bandwidth as in equation (9). According to these estimates, being affiliated with the President's coalition in close races entails an increase in per-capita infrastructure transfers by $40.7 \%$ (twocandidate) or by $32.9 \%$ (three-candidate). The estimates on the President's party are never statistically significant. Overall, the size of the effect of political alignment in the RDD estimations is somehow larger than the effect in the OLS or diff-in-diff estimations. Also this result could receive a twofold explanation: on the one hand, the RDD setup controls for unobservables removing omitted bias; on the other hand, the RDD effect is identified for close electoral races only, where the impact of political alignment might be higher because of tactical motivations, as predicted by our model.

Table 7 also confirms the OLS and diff-in-diff evidence on the per-capita infrastructure transfers received from the federal government in the first two years of the municipal mandate (when the federal elections are approaching). There is no evidence of opportunistic transfers in proximity of federal elections. This result highlights a clear political budget cycle in federal transfers to municipal governments with respect to the timing of municipal elections. And it also reinforces the idea that mayors can claim the lion's share of the political credit from larger transfers (i.e., that the parameter $\theta$ in our model is greater than zero), because tactical redistribution takes place only in proximity of the elections for mayor and not of the elections for the Brazilian President.

Figure 3 shows the estimated spline polynomials in $M V P_{i m}$ to highlight not only the jump in federal transfers at $M V P_{i m}=0$, but also the shape of the relationship between federal transfers and political competition for aligned municipalities (on the right of the zero threshold) and unaligned municipalities (on the left of the zero threshold). This is a way to indirectly assess Proposition 2 in our model. With respect to the President's coalition, Figure 3 clearly shows that the RDD estimate is driven by a sizable cut in transfers to unaligned municipalities close to the zero threshold. In other words, the central 
government penalizes municipalities ruled by mayors belonging to the opposition coalition, especially if they won by a narrow margin, thereby tying the hands of its (political) enemies for the next electoral race. This evidence on the left of zero is consistent with the theoretical prediction in Proposition 2. But the evidence on the right of zero does not show a stark increase in transfers to aligned municipalities that won by a narrow margin. On the contrary, there is some evidence that the federal government gives more money to its strongholds (where $M V P_{i m}$ is positive and very high), although we do not know if this is driven by the (endogenous) local characteristics of these municipalities or by political motivations (as predicted by Cox and McCubbins, 1986). In addition, note that the tails of both polynomials are not accurately estimated because of the small sample size.

Our model assumes that federal transfers improve the reelection prospects of the incumbent, as long as there are political credit spillovers. The effect of transfers on electoral outcomes has been estimated by others using Brazilian data (e.g., Brollo et al., 2010; Litschig and Morrison, 2010) and our framework does not allow us to credibly identify it. But it is still interesting to identify the effect of political alignment per se on the future reelection of the incumbent political party. Keeping in mind, of course, that this differential incumbency advantage (if any) might be driven by many factors, beyond the amount of politically motivated transfers received by the municipality in the last two years of the mandate. For instance, a positive impact of political alignment on reelection might capture a "bandwagon" effect on the side of voters and interest groups, prone to support politicians connected with the national leader who won the last presidential election. In the first two columns of Table 8, we repeat our RDD estimations with the incumbent party's reelection as dependent variable. Being aligned with the party of the President increases reelection chances either by $27.2 \%$ (two-candidate) or by $23.5 \%$ (three-candidate). Being aligned with the government coalition has either no statistically significant effect (two-candidate) or increases reelection chances by $19.8 \%$. These results, however, are not robust to the use of local linear regression as estimation method.

Our model also assumes that aligned mayors are a valuable asset for the President. This could be due to electoral advantages (if mayors were instrumental to find votes for the aligned presidential candidate), rent-seeking, or simple policy congruence. To assess the plausibility of the first channel, in the last two columns of Table 8 , we repeat our RDD 
estimations with the municipal vote share of the Brazilian President (or the candidate of the same party) in the future presidential election as dependent variable. The baseline estimates with spline polynomial approximation point to a gain of about 2 (coalition) or 3 (party) percentage points for presidential candidates who can count on aligned mayors at the municipal level. Yet, results are not robust to three-candidate races or the use of local linear regression. There is some evidence, however, that at least part of the political capital associated with aligned mayors might come from electoral advantages.

\subsection{Treatment effect heterogeneity}

In Table 9 and Table 10, we estimate equation (10) to assess heterogeneity (if any) in the treatment effect. This a way to evaluate the comparative statics implications of our model. We consider two dimensions: (i) whether the value of political capital for the central government is high or not; and (ii) whether the transfers are expected to have a strong impact on the electoral outcome or not. ${ }^{17}$ As empirical proxies for the first dimension, we use two measures: (i) the population size of the municipality; (ii) whether there is a local radio station or not. The intuition behind these measures is that in small municipalities or in municipalities without radio station local politicians have a strong role in influencing the public opinion, and are therefore valuable allies for the President. ${ }^{18}$

The estimation results in Table 9 confirm the theoretical predictions. There, we can see that the effect of political alignment on federal transfers is much stronger in municipalities without a local radio station and in small municipalities (i.e., with a population size below the median). ${ }^{19}$ As a matter of fact, in both two-candidate and three-candidate races, political alignment almost doubles the amount of equilibrium transfers in municipalities without a radio station and in municipalities with below-median population, while the effect is not statistically significant in the others.

As empirical proxies for the second heterogeneity dimension, we use three measures: (i) whether the incumbent mayor is allowed to run for reelection or faces a binding term limit;

\footnotetext{
${ }^{17}$ Unfortunately, we do not have a good proxy for electoral uncertainty in our data, so that we can only test the above two comparative statics results.

${ }^{18}$ Ferraz and Finan (2011) use random corruption audit reports to show that political accountability is lower in municipalities without a local radio station.

${ }^{19}$ The results on population size are robust to the estimation of a continuous version of equation (10), with the exact number of resident inhabitants in the place of $D_{i m}$ (available upon request).
} 
(ii) whether the incumbent mayor is aligned with the state governor or not; (iii) whether the turnout in municipal elections is high or low (based on the median turnout in the last municipal election). Here, the idea is that mayors who can run for reelection, or may have a hard time obtaining discretionary resources from other sources, are going to put more effort in using the additional revenues for political purposes. ${ }^{20}$ Moreover, irrespective of the mayor's effort, increased municipal revenues can be expected to be more effective in terms of electoral outcomes where turnout is high.

The estimation results in Table 10 confirm the theoretical predictions. The effect of political alignment on transfers is much higher for first-term mayors, for mayors unaligned with the state governor, and in municipalities characterized by high turnout in the last municipal election. In two-candidate races, for mayors who can run for reelection and in municipalities with above-median turnout, political alignment almost doubles the amount of transfers; for mayors who cannot count on the support of the state governor, the increase in transfers induced by political alignment is equal to about one-third. The effect is instead not statistically significant in the other municipalities.

\subsection{Validity tests}

In order for our RDD econometric strategy to be internally valid, as discussed in Section 2.2 , political parties must not be able to sort above the threshold of zero margin of victory. In other words, political parties, even when they control the federal government, should not be able to manipulate electoral outcomes in close elections. To check for the absence of manipulative sorting, we perform: (i) visual inspection of the histograms of $M V P_{i m}$ in Figure 4; and (ii) formal tests of the continuity of the density at $M V P_{i m}=0$, in the spirit of McCrary (2008), in Figure 5. The latter procedure tests the null hypothesis of continuity of the density of the margin of victory at the zero threshold, and it is implemented by running kernel local linear regressions of the log of the density separately on both sides of zero. None of these procedures shows any evidence of manipulative sorting around the zero threshold. This means that (ex-post) close races are really decided by random shocks, rather than choice variables such as federal transfers or campaigning effort and ability.

\footnotetext{
${ }^{20}$ Consistently with this conjecture, De Janvry, Finan, and Sadoulet (2009) find that the performance of a cash transfer program intended to reduce school dropout is improved in municipalities where mayors can be reelected. And mayors with good program performance are more likely to get reelected.
} 
In Table 11, we further check for discontinuities of the 2000 Census variables and geographic location at the zero threshold by implementing a set of balance tests, which are performed estimating equation (8) with the town-specific characteristics $W_{i}$ as dependent variables. As these variables are predetermined with respect to the treatment (political alignment), we should observe no discontinuity, as long as there is no manipulative sorting around the zero threshold. This is indeed the case, as all of the variables are balanced around the threshold, excluding a few exceptions for geographical variables in three-candidate races with respect to the President's party.

Finally, in the spirit of Imbens and Lemieux (2008), in Table 12 we implement placebo tests by estimating the treatment effect at fake thresholds, where there should be no effect. In particular, we look at the median on the left and on the right of the threshold of zero margin of victory. We then estimate the treatment effect on the outcome variables for which we have significant baseline results (last two-year transfers, incumbent party's reelection, and President's vote share) using the spline polynomial approximation. ${ }^{21}$ With only one exception, probably due to sample noise, the effects at the fake thresholds are never statistically different from zero.

\section{Conclusion}

In this paper, we document the existence of (sizable) tactical motivations in the allocation of federal transfers by the Brazilian government, aimed at penalizing unaligned municipalities where mayors belonging to the opposition coalition won by a narrow margin. Our RDD estimates - which accommodate for the presence of both time-invariant and time-varying confounding factors - show that mayors politically aligned with the Brazilian President receive larger federal transfers in (ex-ante) close races, by an amount that varies from $26 \%$ to $41 \%$ according to the used estimation method or the measure of political alignment. The results are statistically significant only for federal transfers received in the last two years of the mayoral term (pointing to the existence of a relevant political budget cycle in Brazilian municipal revenues) and for federal transfers in infrastructure (which are highly discretionary and linked to projects that are visible to voters). The normative

\footnotetext{
${ }^{21}$ Placebo estimates for first two-year transfers are also never statistically different from zero (available upon request).
} 
implications of our empirical findings call for a financing system of infrastructure projects that should emphasize the fiscal responsibility of local governments, rather than central transfers, which appear to be strongly influenced by political considerations.

\section{References}

Arulampalam W., S. Dasgupta, A. Dhillon, and B. Dutta (2009): "Electoral Goals and Center-state Trasnfers: A Theoretical Model and Empirical Evidence from India," Journal of Development Economics 88, 103-119.

Berry, C. R., B. C. Burden, and W. G. Howell (2010): "The President and the Distribution of Federal Spending," American Political Science Review 104, 783-799.

Brollo, F. (2008): "Who Is Punishing Corrupt Politicians: Voters or the Central Government? Evidence from the Brazilian Anti-Corruption Program," IGIER working paper No. 336.

Brollo, F., T. Nannicini, R. Perotti, and G. Tabellini (2010): "The Political Resource Curse," NBER working paper No. 15705.

Case, A. (2001): "Election goals and Income Redistribution: recent Evidence from Albania," European Economic Review 45, 405-423.

Caselli, F. and G. Michaels (2009): "Do Oil Windfalls Improve Living Standards? Evidence from Brazil," NBER working paper No. 15550.

Cox, W. G. (2009): "Swing voters, core voters, and distributive politics," in I. Shapiro, S.C. Stokes, E.J Wood, A.S. Kirshner (eds.), Political Representation, pp. 342-357, Cambridge University Press, Cambridge, UK.

Cox, W. G. and M. D. McCubbins (1998): "Electoral Politics as a Redistributive Game," Journal of Politics 48, 370-389.

De Janvry A., F. Finan, and E. Sadoulet (2009): "Local Electoral Incentives and Decentralized Program Performance," mimeo, UC Berkeley. 
Dixit, A. and J. Londreagan (1998): "Fiscal Federalism and Redistributive Politics," Journal of Public Economics 68, 153-180.

Ferraz, C. and F. Finan (2011): "Electoral Accountability and Corruption: Evidence from the Audit Reports of Local Governments," American Economic Review, forthcoming.

Ferreira, F. and J. Gyourko (2009): "Do Political Parties Matter? Evidence from U.S. Cities," Quarterly Journal of Economics 124, 349-397.

Figueiredo, A. C. and F. Limongi (2000): "Presidential Power, Legislative Organization and Party Behavior in Brazil," Comparative Politics 32, 151-170.

Gagliarducci, S., T. Nannicini, and P. Naticchioni (2011): "Electoral Rules and Politicians' Behavior: A Micro Test," American Economic Journal: Economic Policy, forthcoming.

Galasso, V. and T. Nannicini (2011): "Competing on Good Politicians," American Political Science Review 105, 79-99.

Grossman, J. P. (1994): “A Political Theory of Intergovernmental Grants," Public Choice 69, 295-303.

Hahn, J., P. Todd, and W. Van der Klaauw (2001): "Identification and Estimation of Treatment Effects with Regression Discontinuity Design," Econometrica 69, 201-209.

Imbens, G. and T. Lemieux (2008): "Regression Discontinuity Designs: A Guide to Practice," Journal of Econometrics 142, 615-635.

Imbens, G. and K. Kalyanaraman (2009): "Optimal Bandwidth Choice for the Regression Discontinuity Estimator," NBER Working Paper No. 14726.

Johansson, E. (2003): "Intergovernmental Grants as a Tactical Instrument: Empirical Evidence from Swedish Municipalities," Journal of Public Economics 87, 883-915.

Larcinese, V., L. Rizzo, and C. Testa (2006): "Allocating the U.S. Federal Budget to the States: The Impact of the President," Journal of Politics 68, 447-456. 
Lee, D.S. (2008): "Randomized Experiments from Non-random Selection in the U.S. House Elections," Journal of Econometrics 142, 675-697.

Lee, D.S., E. Moretti, and M.J. Butler (2004): "Do Voters Affect or Elect Policies? Evidence from the U.S. House," Quarterly Journal of Economics 119, 807-859.

Levitt, D. S. (1995): "Political Parties and the Distribution of Federal Outlays," American Journal of Political Science 39, 958-980.

Lindbeck, A. and J. W. Weibull (1987): "Balanced-Budget Redistribution as the Outcome of Political Competition," Public Choice 52, 237-297.

Litschig, S. and K. Morrison (2010): "Government Spending and Re-election," mimeo, Universitat Pompeu Fabra.

Manacorda, M., M. Edward, and A. Vigorito (2009): "Government Transfers and Political Support," mimeo, UC Berkeley: Center for International and Development Economics Research.

McCrary, J. (2008): "Manipulation of the Running Variable in the Regression Discontinuity Design: A Density Test," Journal of Econometrics 142, 698-714.

Monteiro, J. and C. Ferraz (2010): "Does Oil Make Leaders Unaccountable? Evidence from Brazil's offshore oil boom," mimeo, PUC-Rio.

Oates, W. E. (1972): Fiscal Federalism, Harcourt Brace Jovanovich, New York, USA.

Pereira, C. and B. Mueller (2002): "Strategic Behavior in a Coalition-Based Presidential System: Executive-Legislative Relations in Budgetary Process in Brazil," mimeo, Annual Meeting of the American Political Science Association.

Pettersson-Lidbom, P. (2008): "Do Parties Matter for Economic Outcomes? A RegressionDiscontinuity Approach," Journal of the European Economic Association 6, 10371056 .

Shepsle. K.A., R.P. Van Houweling, S.J. Abrams, and P.C. Hanson (2009): "The Senate Electoral Cycle and Bicameral Appropriations Politics," American Journal of Political Science 53, 343-359. 
Sollé-Ollé, A. and P. Sorribas-Navarro (2008): "The Effects of Partisan Alignment on the Allocation of Intergovernmental Transfers. Differences-in-differences Estimates for Spain," Journal of Public Economics 92, 2302-2319.

Sollé-Ollé, A. and P. Sorribas-Navarro (2009): "Does Partisan alignment affect the electoral reward of intergovernmental transfers?," mimeo, Universitat de Barcelona.

Stromberg, D. (2008): "How the Electoral College Influences Campaigns and Policy: The Probability of Being Florida," American Economic Review 98, 769-807.

Veiga, G. L. and M. M. Pinho (2007): "The Political Economy of Intergovernmental Grants: Evidence from a Maturing Democracy," Public Choice 133, 457-477.

Worthington, A. C. and B. E. Dollery (1998): "The Political Determination of Intergovernmental Grants in Australia," Public Choice 94, 299-315. 


\section{Appendix}

\section{Proof of Proposition 1}

Define $\underline{\tau}=E\left[\tau \mid P_{i}=0, M V P_{i}^{0}=0\right]=\lim _{M V P_{i}^{0} \uparrow 0} \tau_{i}$ as the optimal transfers to unaligned municipalities in close races, and $\bar{\tau}=E\left[\tau \mid P_{i}=1, M V P_{i}^{0}=0\right]=\lim _{M V P_{i}^{0} \downarrow 0} \tau_{i}$ as the optimal transfers to aligned municipalities in close races. These quantities are derived from the following first-order conditions, respectively: $(1-\theta) U^{\prime}(\underline{\tau})-\frac{R \theta f^{\prime}(\underline{\tau})}{\sigma} \phi\left[\frac{-\theta f(\underline{\tau})}{\sigma}\right]-C^{\prime}(\underline{\tau})=0$; $(1-\theta) U^{\prime}(\bar{\tau})+\frac{R \theta f^{\prime}(\bar{\tau})}{\sigma} \phi\left[\frac{\theta f(\bar{\tau})}{\sigma}\right]-C^{\prime}(\bar{\tau})=0$. It follows that: $\underline{\tau}=\tau^{*}-z<\tau^{*}<\bar{\tau}=\tau^{*}+k$, with $z, k>0$, which proves Proposition 1 .

\section{Proof of Proposition 2}

Define the first-order condition in equation (4) as $g\left(\tau_{i}, M V P_{i}^{0}\right)=0$. Therefore, at $P_{i}=1$ : $\left(\partial \tau_{i} / \partial M V P_{i}^{0}\right)=-\left(\partial g / \partial M V P_{i}^{0}\right) /\left(\partial g / \partial \tau_{i}\right)<0$. In fact: $\left(\partial g / \partial \tau_{i}\right)<0$ because of the second-order condition; and $\left(\partial g / \partial M V P_{i}^{0}\right)=-\frac{R \theta f^{\prime}\left(\tau_{i}\right)}{\sigma} \frac{\rho M V P_{i}^{0}+\theta f\left(\tau_{i}\right)}{\sigma} \phi\left[\frac{\rho M V P_{i}^{0}+\theta f\left(\tau_{i}\right)}{\sigma}\right]<0$, as $\phi^{\prime}[x]=-x \phi[x]$. Similarly, at $P_{i}=0:\left(\partial \tau_{i} / \partial M V P_{i}^{0}\right)=-\left(\partial g / \partial M V P_{i}^{0}\right) /\left(\partial g / \partial \tau_{i}\right)<0$, because in this case: $\left(\partial g / \partial M V P_{i}^{0}\right)=\frac{R \theta f^{\prime}\left(\tau_{i}\right)}{\sigma} \frac{\rho M V P_{i}^{0}-\theta f\left(\tau_{i}\right)}{\sigma} \phi\left[\frac{\rho M V P_{i}^{0}-\theta f\left(\tau_{i}\right)}{\sigma}\right]<0$. 


\section{Figures and Tables}

Figure 1 - Politically motivated transfers

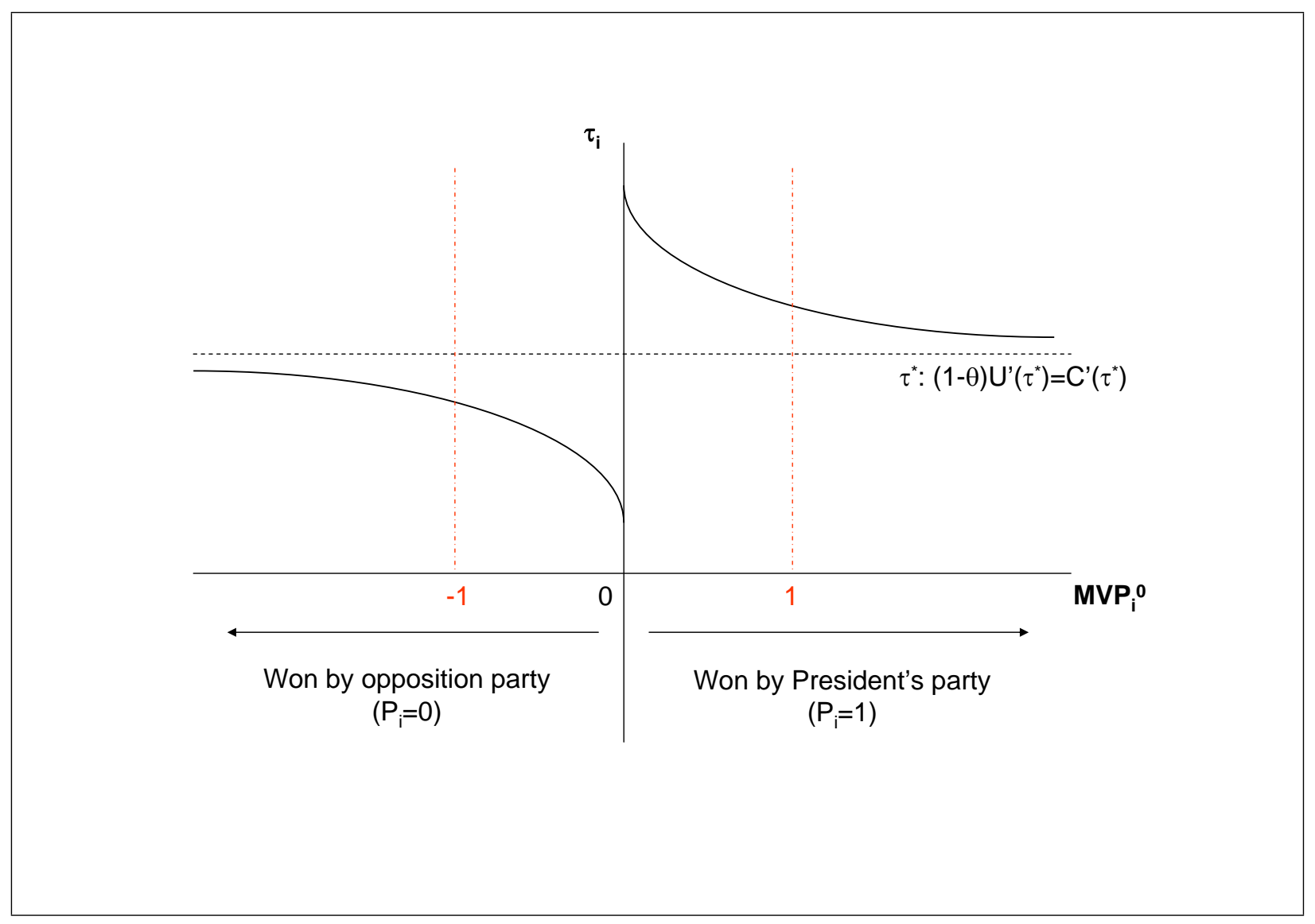

Notes. Politically motivated transfers as a function of the past margin of victory of the candidate aligned with the President. 
Figure 2 - Timing of Brazilian elections

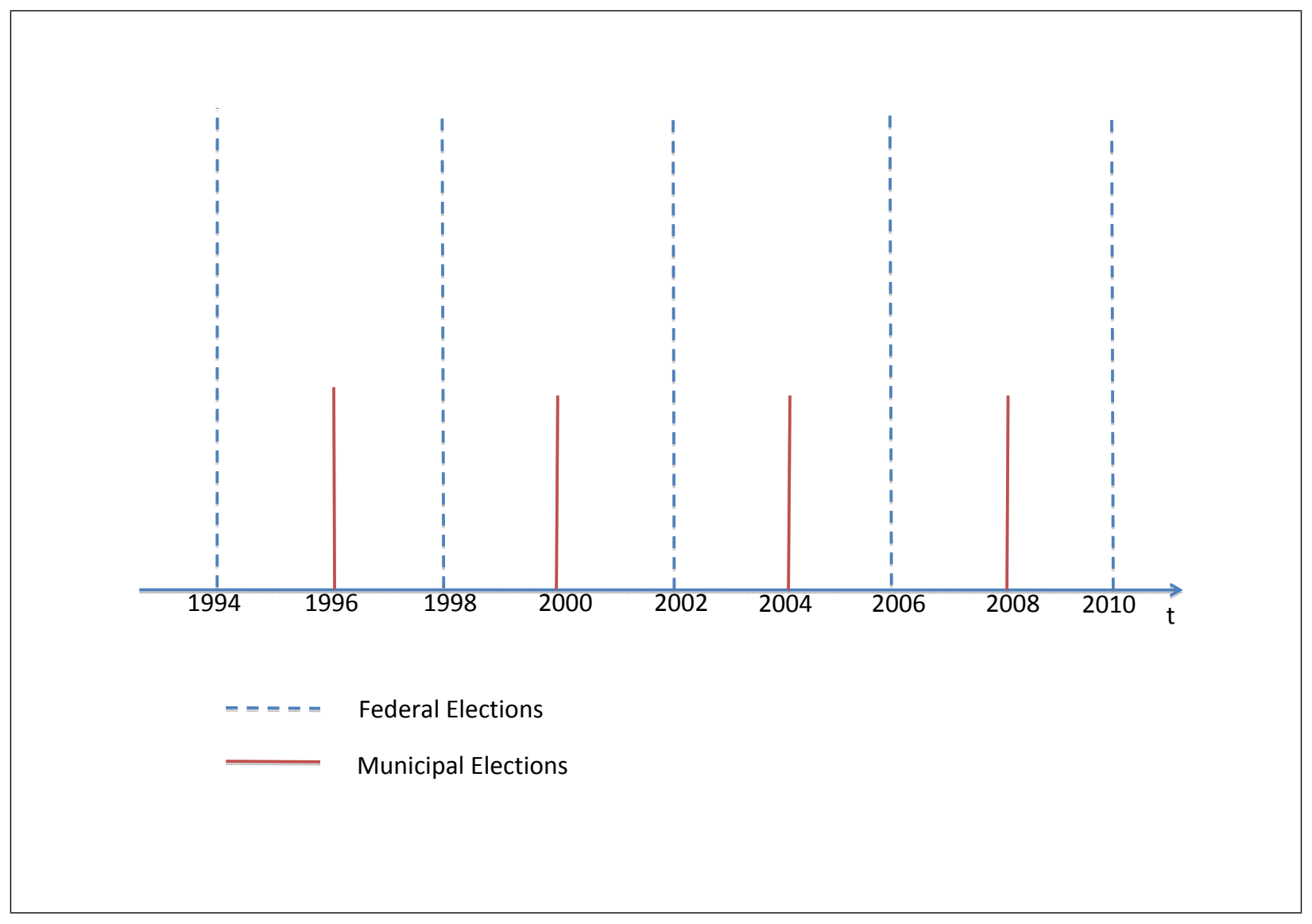

Notes. Timing of federal and municipal elections over the sample period. 
Figure 3 - Political alignment and federal transfers
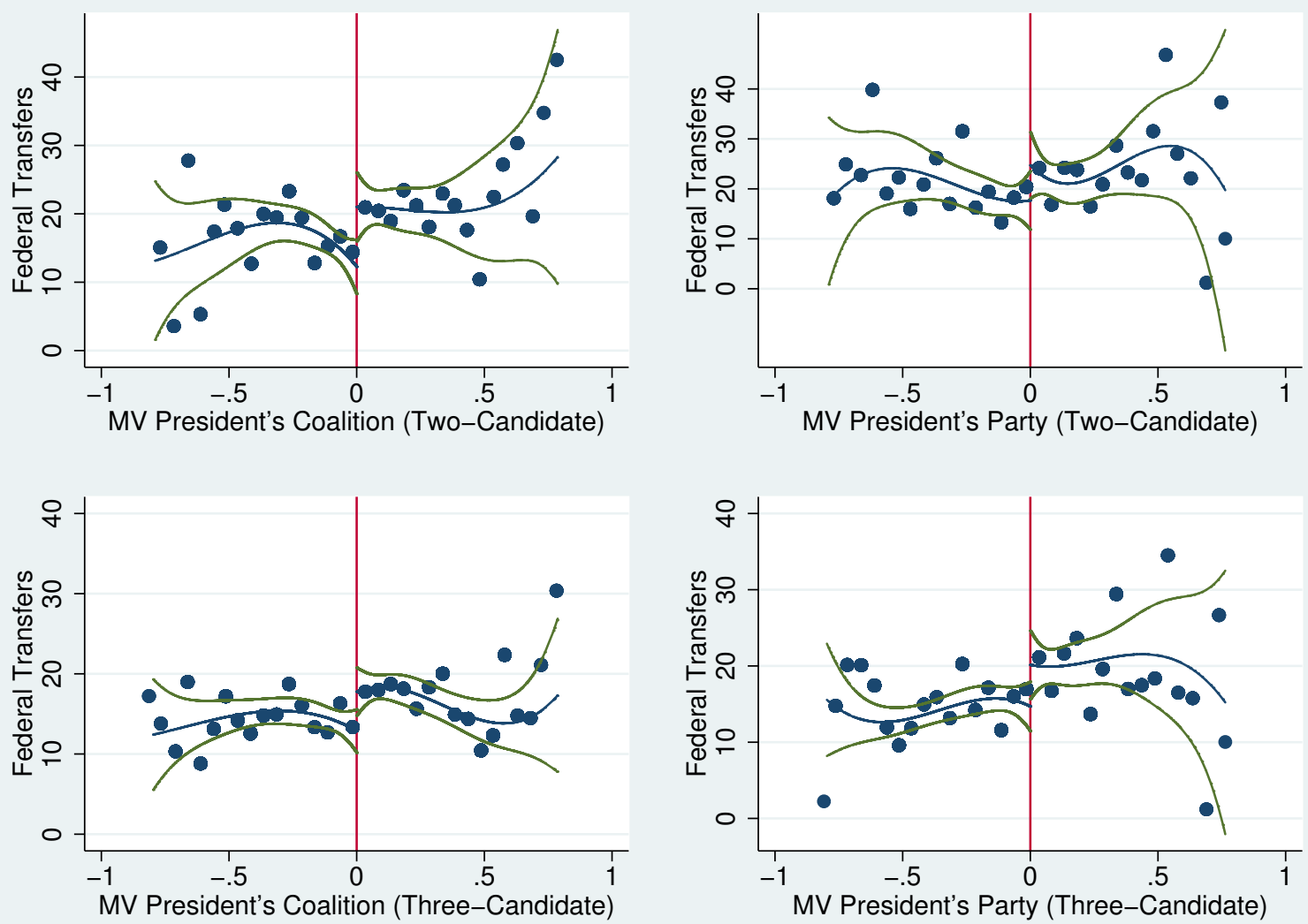

Notes. The central line is a split $3^{\text {rd }}$-order polynomial in the margin of victory of the President's coalition or the President's party, fitted over the interval $[-0.80,+0.80]$; the lateral lines represent the $95 \%$ confidence interval. Scatter points are averaged over 5-unit intervals. Two-candidate (Three-candidate) races are those where only two (three) candidates run for mayor and one of them is affiliated with the President's coalition or party. 
Figure 4 - Histograms of the margin of victory

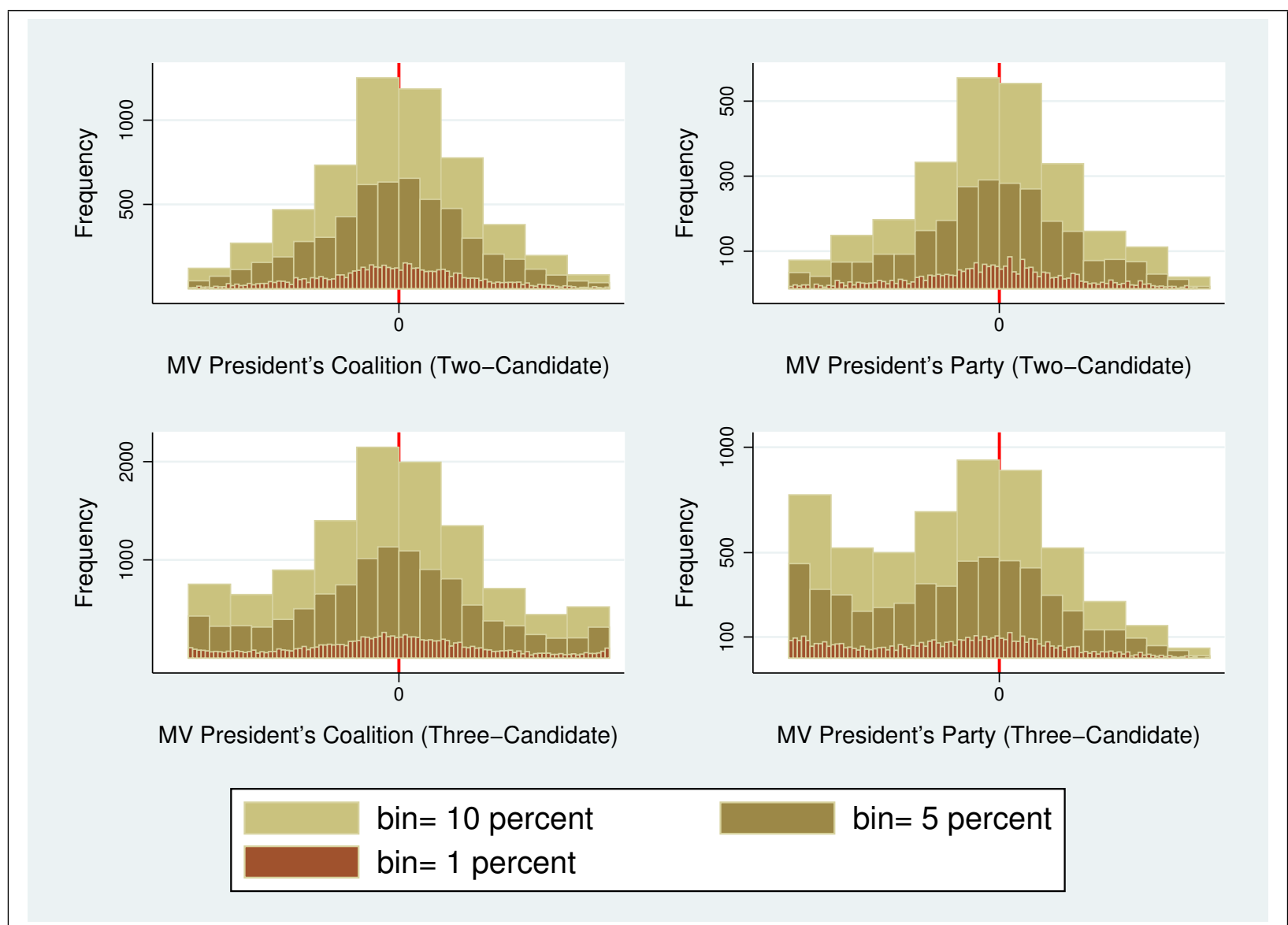

Notes. Frequency of municipalities according to the margin of victory of the President's coalition or the President's party. Two-candidate (Three-candidate) races are those where only two (three) candidates run for mayor and one of them is affiliated with the President's coalition or party. 
Figure 5 - Testing the continuity of the density in close races

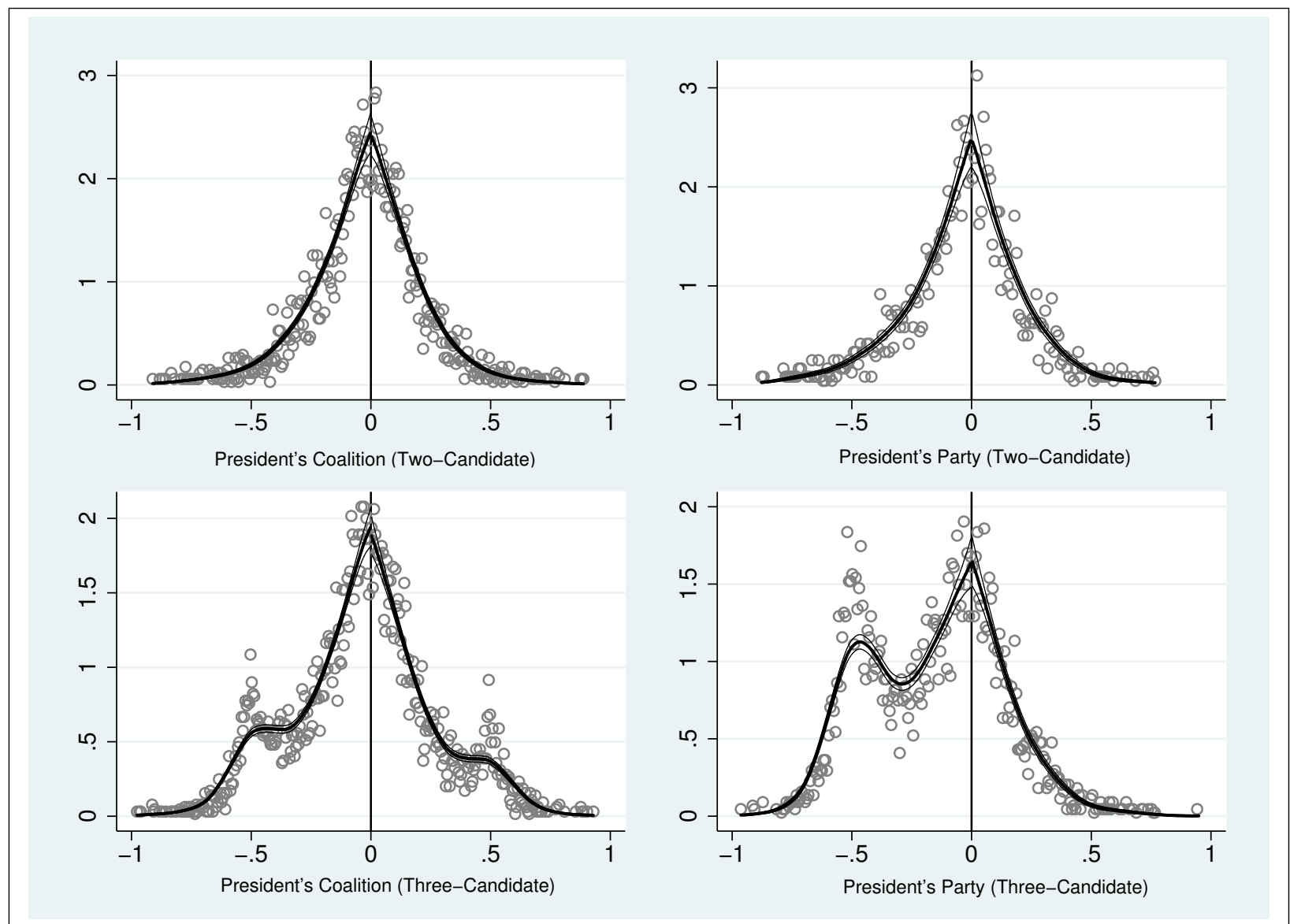

Notes. Weighted kernel estimation of the log density according to the margin of victory of the President's coalition or the President's party, performed separately on either side of the zero threshold. Optimal binwidth and binsize as in McCrary (2008). Two-candidate (Three-candidate) races are those where only two (three) candidates run for mayor and one of them is affiliated with the President's coalition or party. 


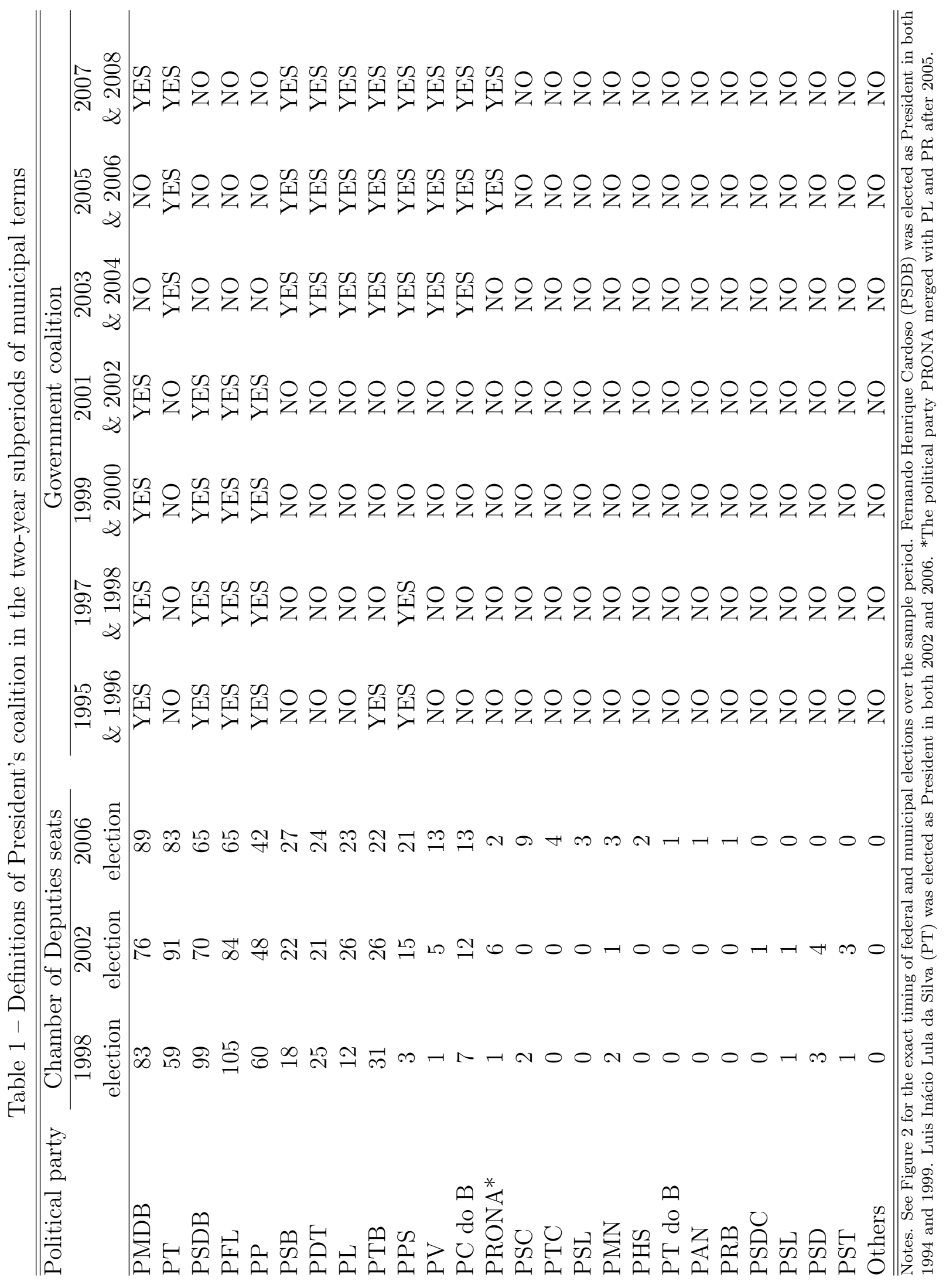




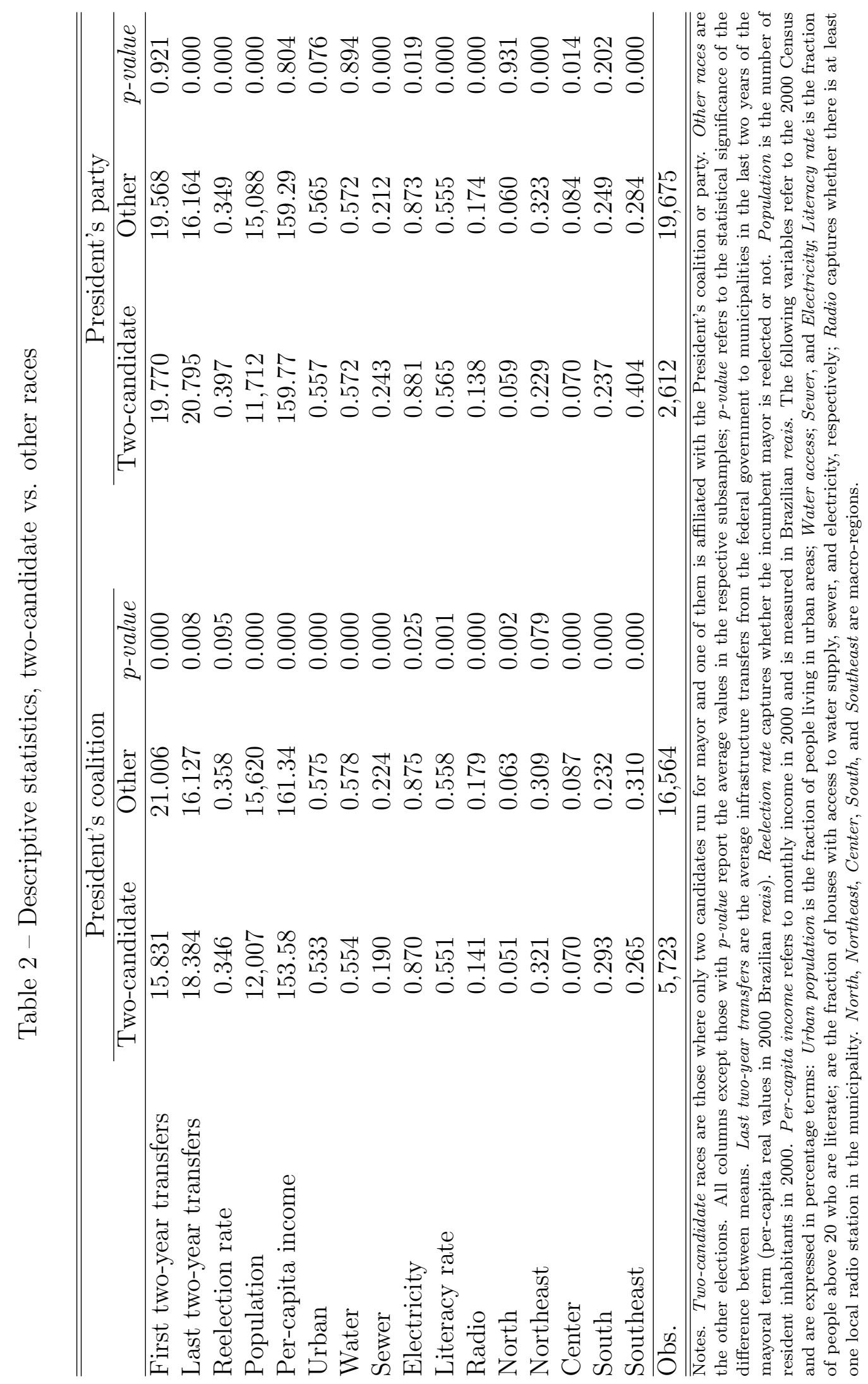




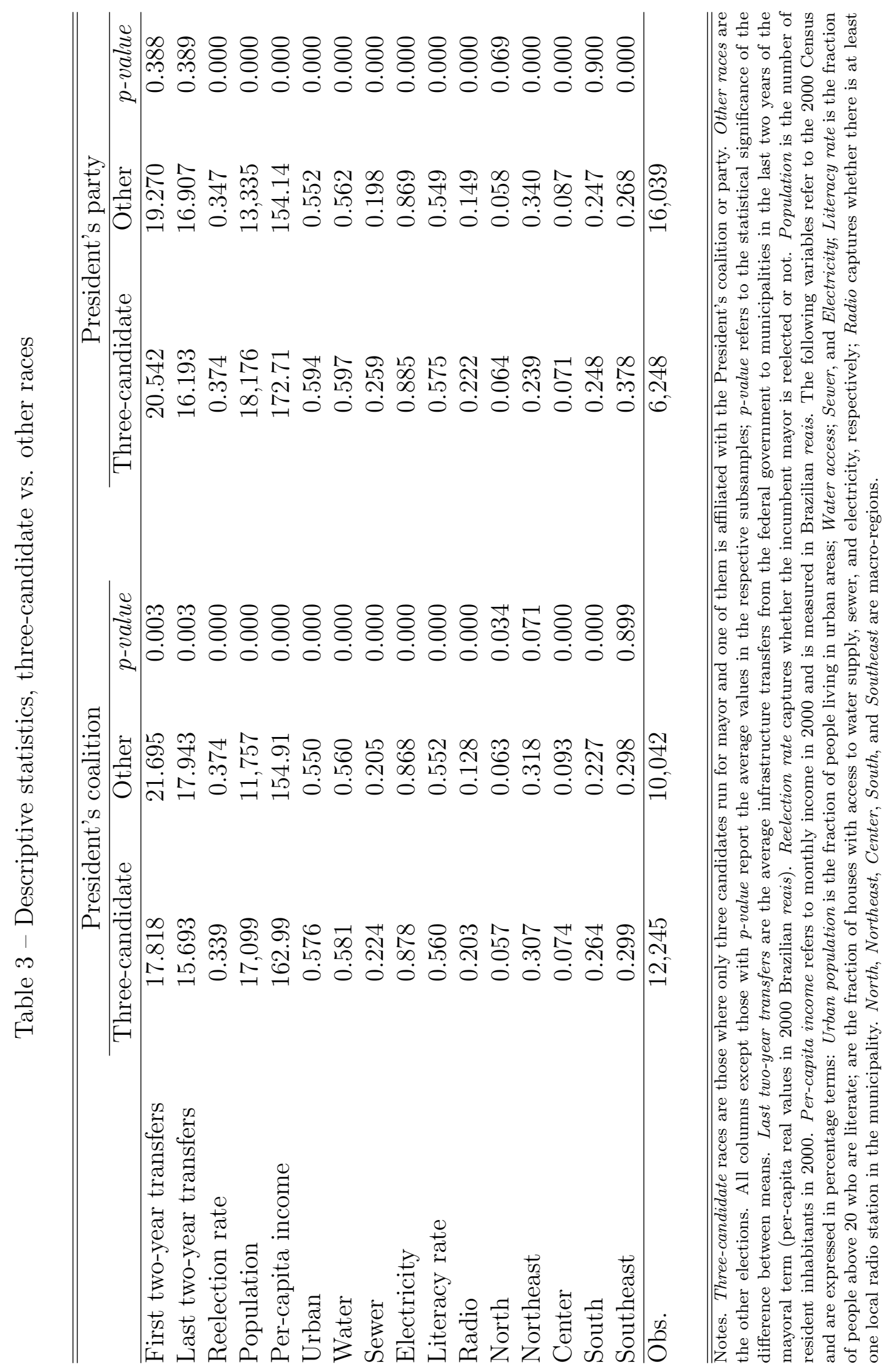




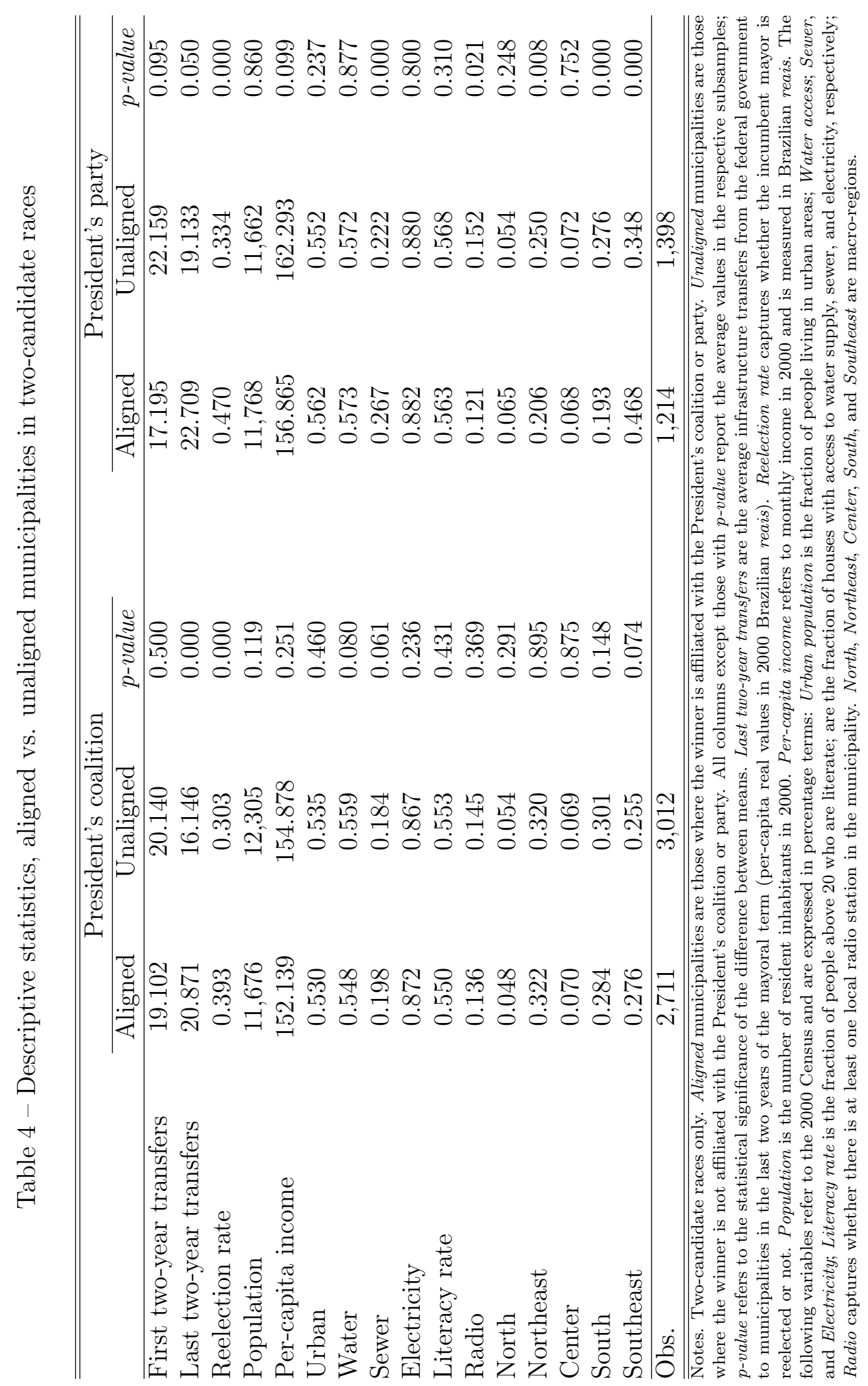




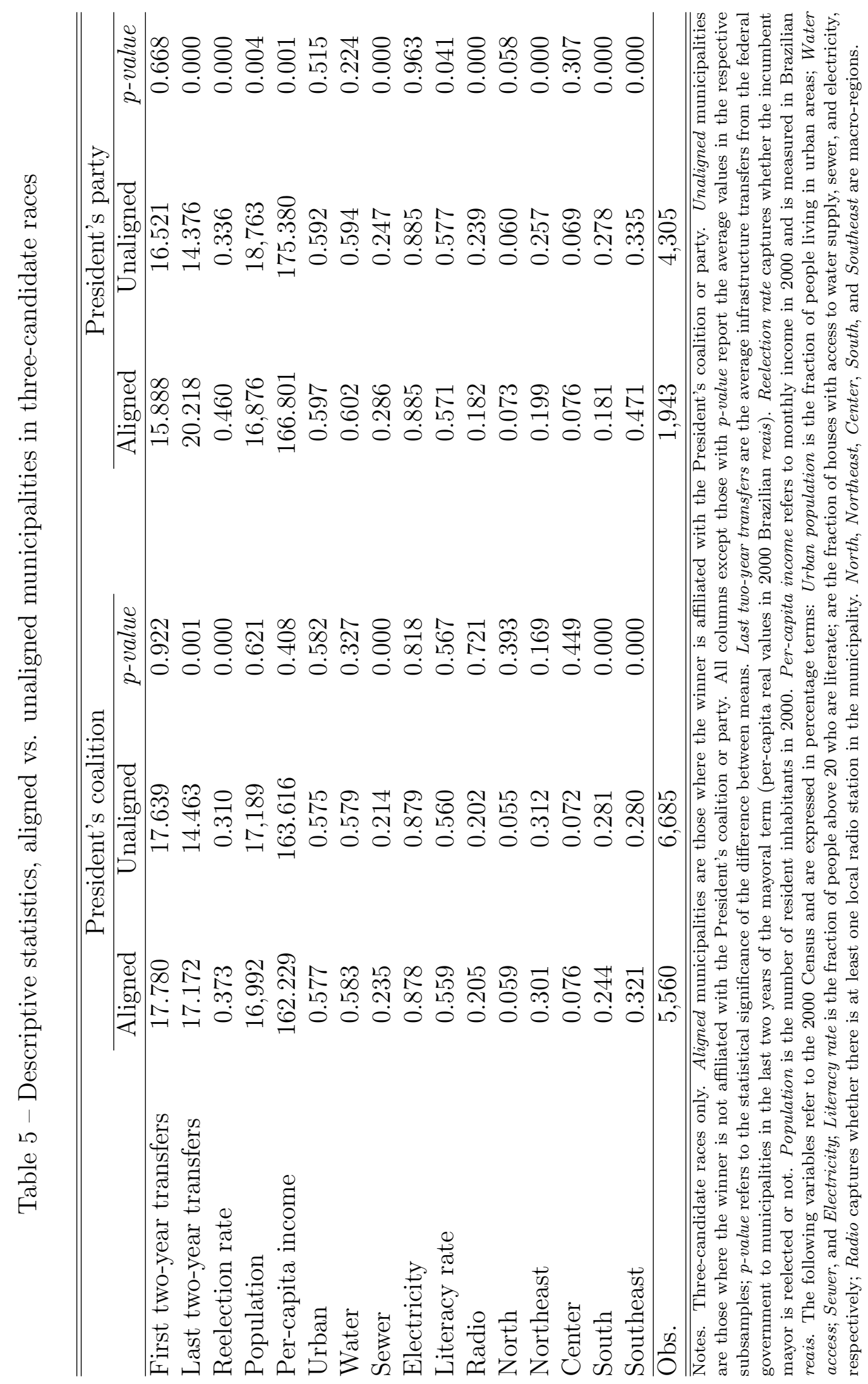


Table 6 - The impact of political alignment on federal transfers, OLS and diff-in-diff

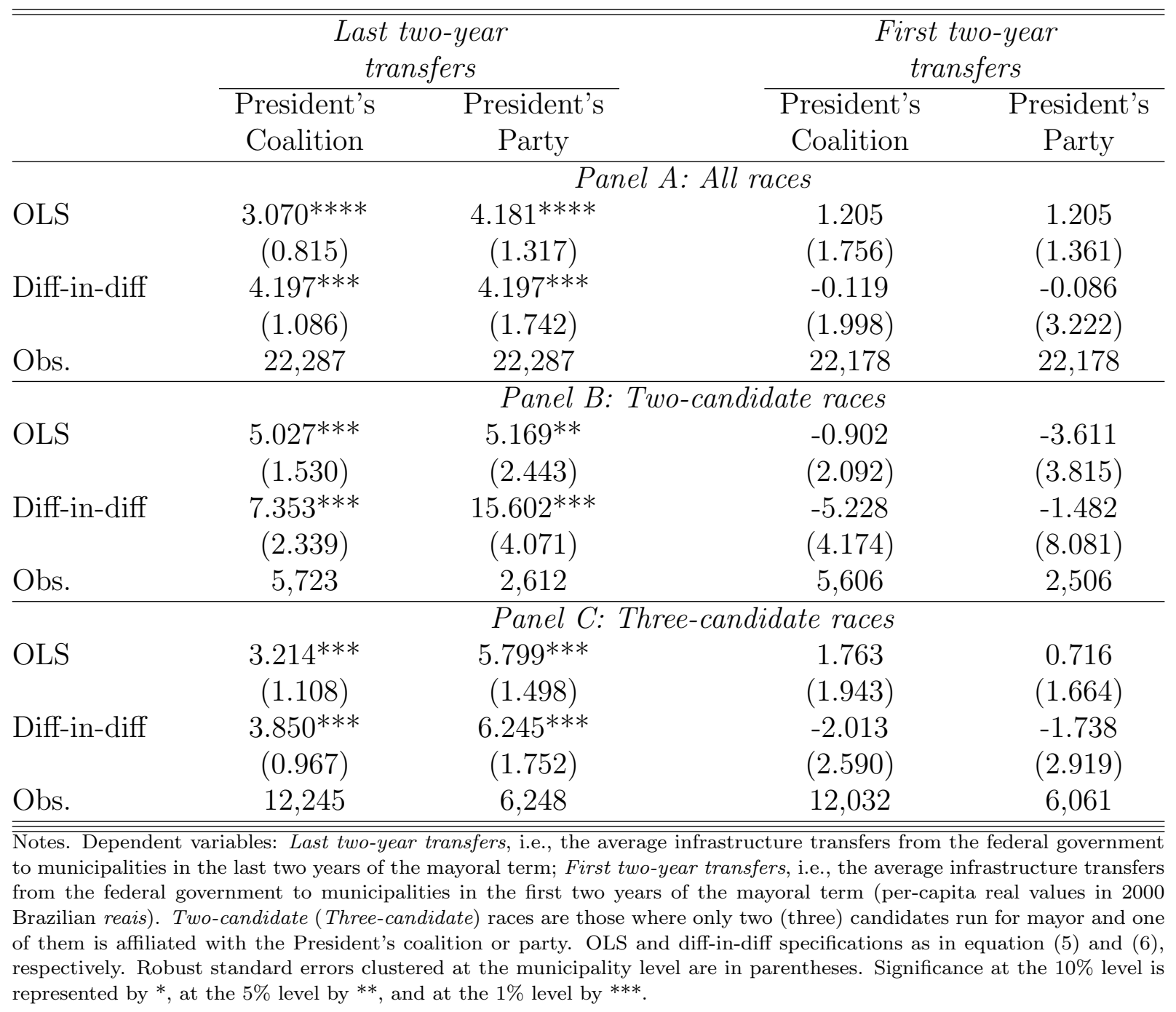


Table 7 - The impact of political alignment on federal transfers, RDD estimates

\begin{tabular}{|c|c|c|c|c|}
\hline & \multicolumn{2}{|c|}{$\begin{array}{l}\text { Last two-year } \\
\text { transfers }\end{array}$} & \multicolumn{2}{|c|}{$\begin{array}{c}\text { First two-year } \\
\text { transfers }\end{array}$} \\
\hline & $\begin{array}{c}\text { President's } \\
\text { Coalition }\end{array}$ & $\begin{array}{c}\text { President's } \\
\text { Party }\end{array}$ & $\begin{array}{l}\text { President's } \\
\text { Coalition }\end{array}$ & $\begin{array}{c}\text { President's } \\
\text { Party }\end{array}$ \\
\hline & \multicolumn{4}{|c|}{ Panel A: Two-candidate races } \\
\hline Spline polynomial & $\begin{array}{l}6.789 * * \\
(3.095)\end{array}$ & $\begin{array}{c}7.694 \\
(5.314)\end{array}$ & $\begin{array}{l}-1.756 \\
(4.442)\end{array}$ & $\begin{array}{l}-0.739 \\
(6.883)\end{array}$ \\
\hline Obs. & 5,723 & 2,612 & 5,606 & 2,506 \\
\hline Local linear regression & $\begin{array}{l}7.477^{* *} \\
(3.150)\end{array}$ & $\begin{array}{c}6.155 \\
(5.221)\end{array}$ & $\begin{array}{l}-2.609 \\
(4.220)\end{array}$ & $\begin{array}{c}6.048 \\
(6.302)\end{array}$ \\
\hline Optimal $h$ & 25 & 11 & 25 & 11 \\
\hline Obs. & 4,430 & 1,188 & 4,329 & 1,133 \\
\hline & \multicolumn{4}{|c|}{ Panel B: Three-candidate races } \\
\hline Spline polynomial & $\begin{array}{l}4.134^{* *} \\
(2.085)\end{array}$ & $\begin{array}{l}5.550^{*} \\
(3.225)\end{array}$ & $\begin{array}{l}-2.403 \\
(2.723)\end{array}$ & $\begin{array}{l}-1.700 \\
(4.540)\end{array}$ \\
\hline Obs. & 12,245 & 6,248 & 12,032 & 6,061 \\
\hline Local linear regression & $\begin{array}{c}5.170^{* * *} \\
(1.991)\end{array}$ & $\begin{array}{c}4.453 \\
(3.519)\end{array}$ & $\begin{array}{l}-1.645 \\
(2.725)\end{array}$ & $\begin{array}{c}0.876 \\
(3.634)\end{array}$ \\
\hline Optimal $h$ & 22 & 11 & 22 & 11 \\
\hline Obs. & 7,248 & 1,948 & 7,120 & 1,878 \\
\hline
\end{tabular}


Table 8 - The impact of political alignment on electoral outcomes, RDD estimates

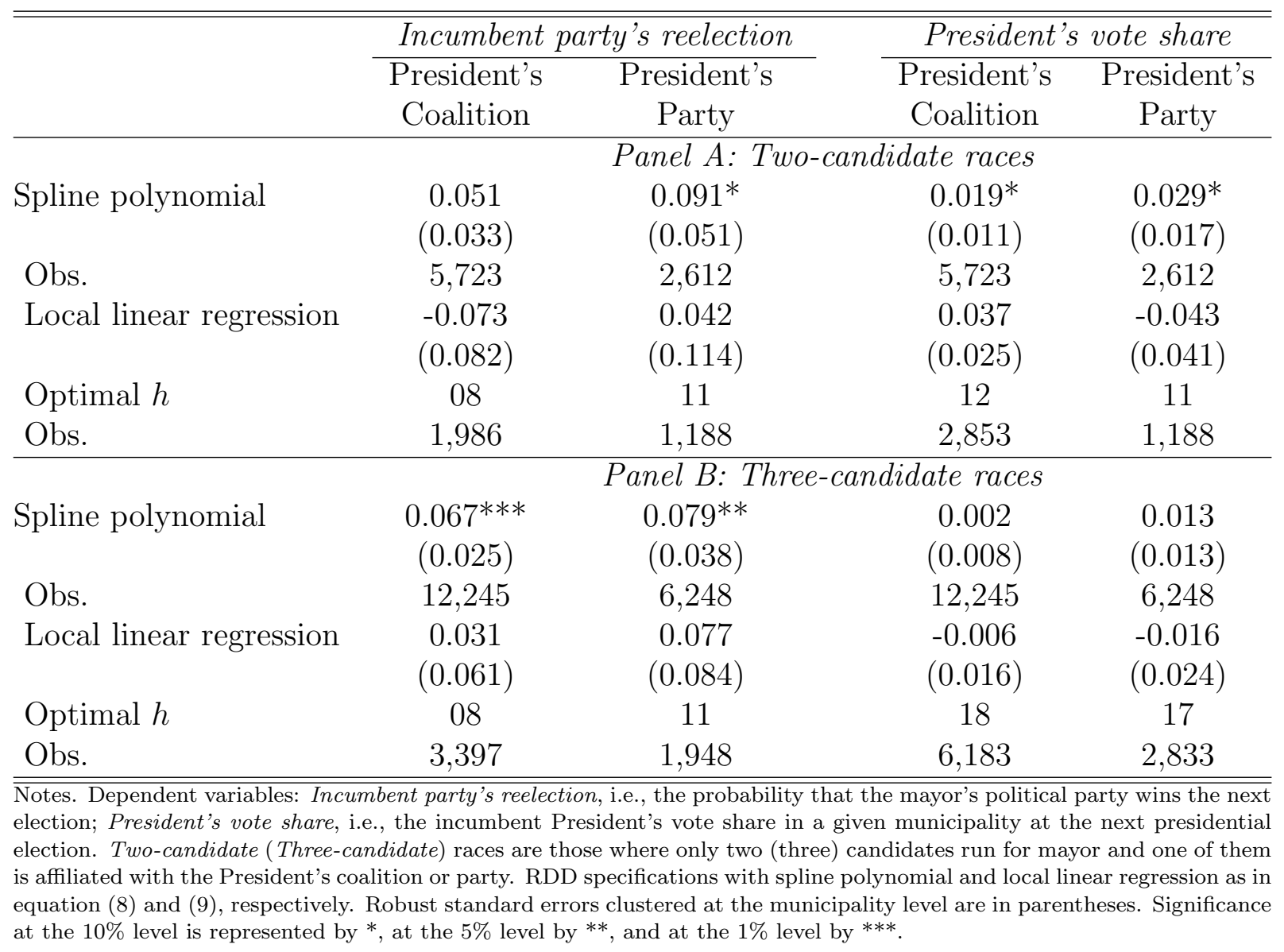


Table 9 - Last two-year transfers and political capital, RDD heterogeneity

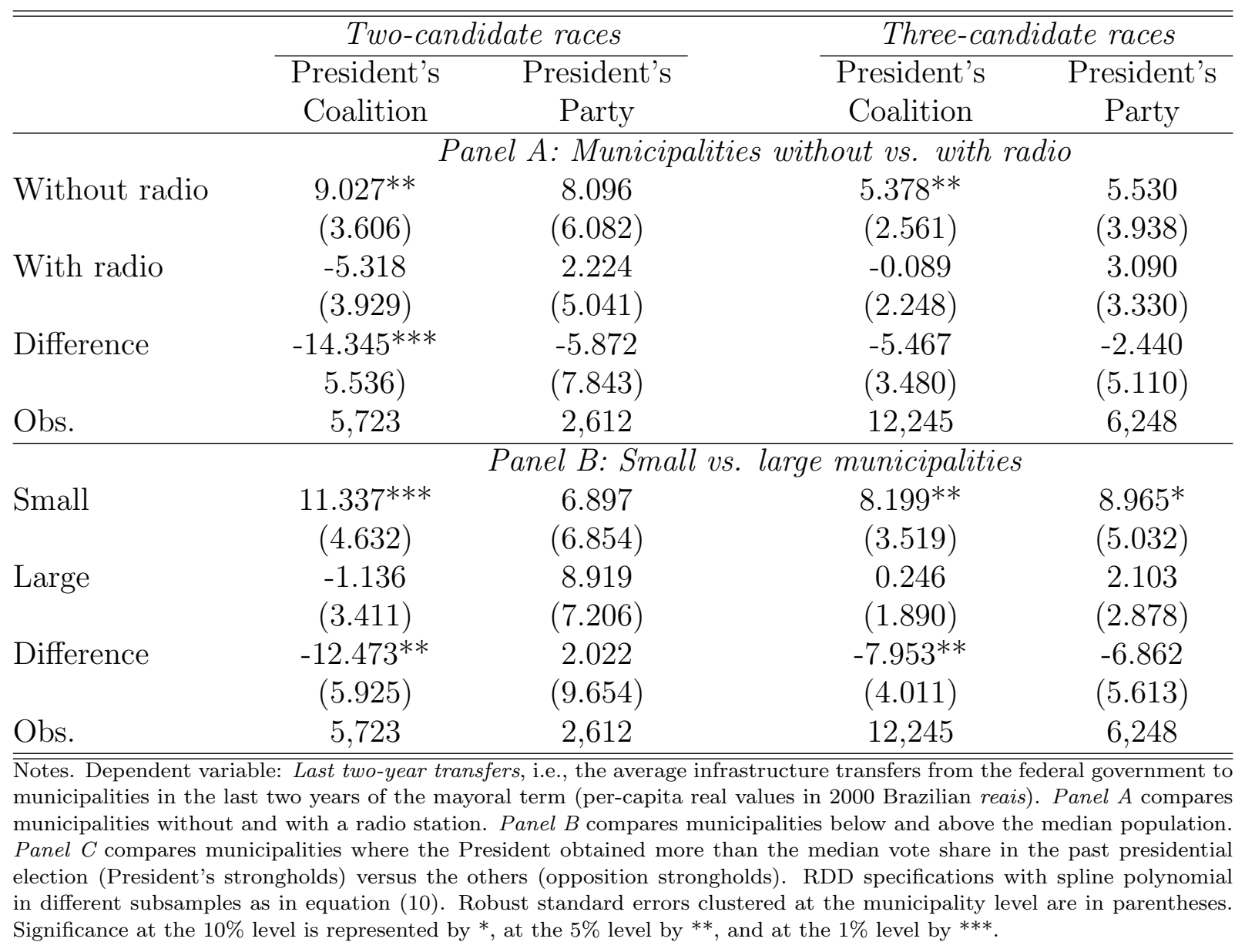


Table 10 - Last two-year transfers and effectiveness, RDD heterogeneity

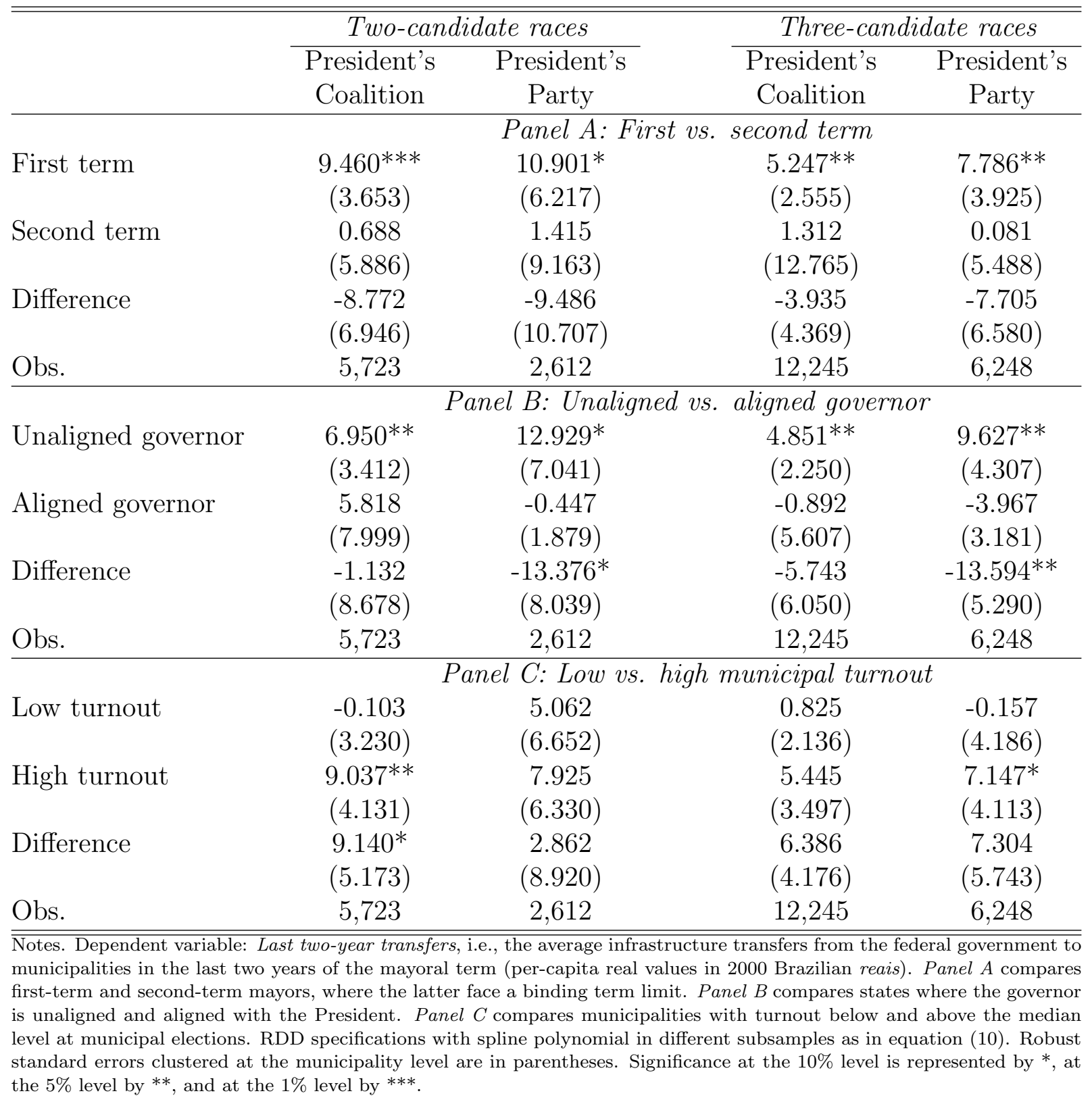


Table 11 - Testing the continuity of town characteristics in close races

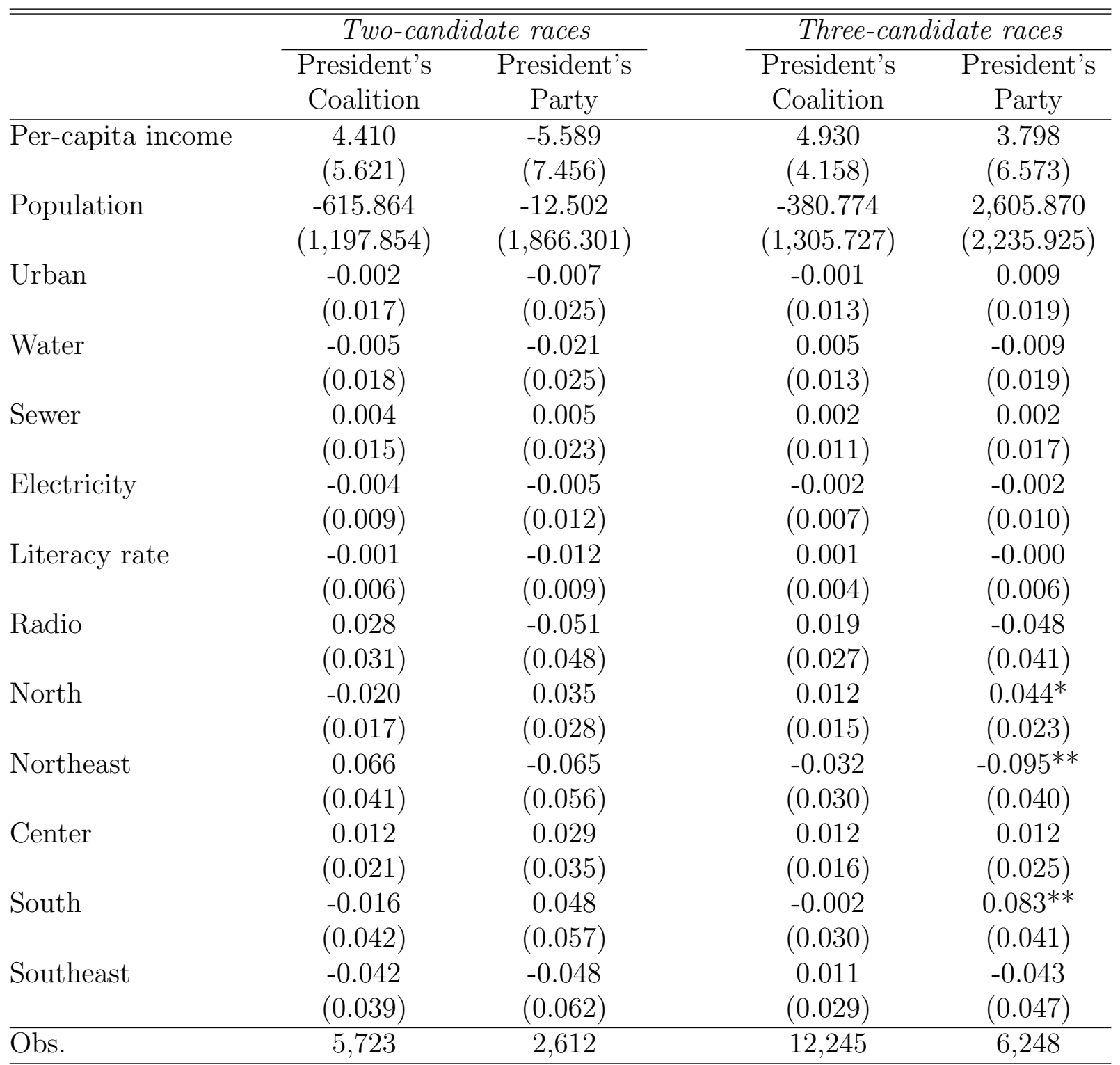

$\overline{\text { Notes. Estimated discontinuities of town characteristics at the threshold of zero margin of victory. RDD specifications with }}$ spline polynomial as in equation (8). Population is the number of inhabitants in 2000. Per-capita income refers to monthly income in 2000 and is measured in Brazilian reais. The following variables refer to the 2000 Census and are expressed in percentage terms: Urban population is the fraction of people living in urban areas; Literacy rate is the fraction of people above 20 who are literate; Water access, Sewer, and Electricity are the fraction of houses with access to water supply, sewer, and electricity, respectively; Radio captures whether there is at least one radio station in the municipality. North, Northeast, Center, South, and Southeast are macro-regions. Robust standard errors clustered at the municipality level are in parentheses. Significance at the $10 \%$ level is represented by *, at the $5 \%$ level by **, and at the $1 \%$ level by ***. 
Table 12 - Placebo tests at fake electoral thresholds

\begin{tabular}{|c|c|c|c|c|c|c|}
\hline & $\begin{array}{c}\text { President's } \\
\text { Coalition }\end{array}$ & $\begin{array}{l}\text { President's } \\
\text { Party }\end{array}$ & $\begin{array}{c}\text { President's } \\
\text { Coalition }\end{array}$ & $\begin{array}{c}\text { President's } \\
\text { Party }\end{array}$ & $\begin{array}{c}\text { President's } \\
\text { Coalition }\end{array}$ & $\begin{array}{c}\text { President's } \\
\text { Party }\end{array}$ \\
\hline & \multicolumn{6}{|c|}{ Panel A1: Median on the left, two-candidate races } \\
\hline & \multicolumn{2}{|c|}{$\begin{array}{l}\text { Last two-year } \\
\text { transfers }\end{array}$} & \multicolumn{2}{|c|}{$\begin{array}{l}\text { Incumbent party's } \\
\text { reelection }\end{array}$} & \multicolumn{2}{|c|}{$\begin{array}{l}\text { President's } \\
\text { vote share }\end{array}$} \\
\hline & -9.186 & -10.015 & -0.050 & 0.051 & -0.023 & 0.021 \\
\hline & $(7.614)$ & $(9.560)$ & $(0.144)$ & $(0.167)$ & $(0.042)$ & $(0.056)$ \\
\hline \multirow[t]{5}{*}{ Obs. } & 785 & 785 & 785 & 785 & 785 & 785 \\
\hline & & Panel A2: & edian on the & left, three-ca & date races & \\
\hline & $\begin{array}{l}\text { Last } t \\
\text { tran }\end{array}$ & $\begin{array}{l}\text { o-year } \\
\text { fers }\end{array}$ & $\begin{array}{r}\text { Incumbe } \\
\text { reele }\end{array}$ & $\begin{array}{l}\text { t party's } \\
\text { tion }\end{array}$ & $\begin{array}{l}\text { Prest } \\
\text { vote }\end{array}$ & $\begin{array}{l}\text { ent's } \\
\text { hare }\end{array}$ \\
\hline & -2.340 & -2.701 & 0.102 & 0.086 & -0.015 & 0.017 \\
\hline & $(4.799)$ & $(8.691)$ & $(0.122)$ & $(0.123)$ & $(0.030)$ & $(0.043)$ \\
\hline \multirow[t]{5}{*}{ Obs. } & 1,167 & 1,167 & 1,167 & 1,167 & 1,167 & 1,167 \\
\hline & & Panel B1: & edian on the & right, two-co & date races & \\
\hline & $\begin{array}{l}\text { Last } t \\
\text { trar }\end{array}$ & $\begin{array}{l}\text { o-year } \\
\text { fers }\end{array}$ & $\begin{array}{r}\text { Incumbe } \\
\text { reele }\end{array}$ & $\begin{array}{l}\text { t party's } \\
\text { tion }\end{array}$ & $\begin{array}{l}\text { Prest } \\
\text { vote }\end{array}$ & $\begin{array}{l}\text { ent's } \\
\text { hare }\end{array}$ \\
\hline & 4.118 & -1.200 & 0.049 & -0.203 & -0.009 & $-0.064^{* *}$ \\
\hline & $(5.841)$ & (10.198) & $(0.081)$ & $(0.135)$ & $(0.023)$ & $(0.033)$ \\
\hline \multirow[t]{5}{*}{ Obs. } & 2,711 & 1,214 & 2,711 & 1,214 & 2,711 & 1,214 \\
\hline & & Panel B2: & dian on the & ight, three-c & idate races & \\
\hline & $\begin{array}{l}\text { Last } t \\
\text { trar }\end{array}$ & $\begin{array}{l}\text { o-year } \\
\text { fers }\end{array}$ & $\begin{array}{r}\text { Incumbe } \\
\text { reele }\end{array}$ & $\begin{array}{l}\text { t party's } \\
\text { tion }\end{array}$ & $\begin{array}{l}\text { Pres } \\
\text { vote }\end{array}$ & $\begin{array}{l}\text { ent's } \\
\text { hare }\end{array}$ \\
\hline & -0.716 & 4.801 & 0.070 & -0.158 & -0.010 & -0.026 \\
\hline & $(4.892)$ & $(6.932)$ & $(0.063)$ & $(0.105)$ & $(0.018)$ & $(0.025)$ \\
\hline Obs. & 4,444 & 1,943 & 4,444 & 1,943 & 4,444 & 1,943 \\
\hline
\end{tabular}

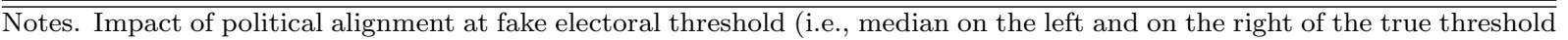
at zero). Dependent variables: Last two-year transfers, i.e., the average infrastructure transfers from the federal government to municipalities in the last two years of the mayoral term (per-capita real values in 2000 Brazilian reais); Incumbent party's reelection, i.e., the probability that the mayor's political party wins the next election; President's vote share, i.e., the incumbent President's vote share in a given municipality at the next presidential election. Two-candidate (Three-candidate) races are those where only two (three) candidates run for mayor and one of them is affiliated with the President's coalition or party. RDD specifications with spline polynomial as in equation (8). Robust standard errors clustered at the municipality level are in parentheses. Significance at the $10 \%$ level is represented by $*$, at the $5 \%$ level by **, and at the $1 \%$ level by ***. 